This is a peer-reviewed, accepted author manuscript of the following research article: Klein, M. (Accepted/In press). Who benefits from attending elite universities? Family background and graduates' career trajectories. Research in Social Stratification and Mobility.

\title{
Who benefits from attending elite universities? Family background and graduates' career trajectories
}

Markus Klein

University of Strathclyde

\begin{abstract}
The literature on social stratification has paid considerable attention to whether and to what extent attending prestigious universities is advantageous for graduates' labor market returns. This paper contributes to the literature by applying a more dynamic perspective in asking whether graduates from prestigious and less prestigious universities differ in their career progression across fourteen years since labor market entry. It further investigates whether graduating from prestigious universities pays off more or less for graduates from different educational backgrounds. The positive selection hypothesis suggests that students most likely to attend prestigious universities will benefit the most. The negative selection hypothesis suggests the opposite. Using multilevel growth curve modeling and the 1970 British Cohort Study $(\mathrm{N}=939)$, the findings show no discernible differences in occupational prestige between graduates from diverse universities. If at all, there is a small Russell Group premium restricted to the early working career. This early Russell Group premium is only found among first-generation graduates providing evidence for the negative selection hypothesis.
\end{abstract}

Keywords: Social inequality, Higher education, Institutional prestige, Intragenerational mobility, Life course 


\section{Introduction}

Research on the labor market consequences of horizontal stratification in postsecondary education has given much attention to whether and to what extent attending prestigious universities is advantageous for graduates' labor market returns (Gerber and Cheung 2008). Studies commonly rank institutions either by 'college quality' - a multidimensional construct including various factors such as mean standardized test scores, expenditures per full-time students, and quality of teaching or facilities, or 'college selectivity'. The latter focuses entirely on mean test scores at admission and is considered a much more accurate measure of institutional prestige (Witteveen and Attewell 2017). Regardless of differences in measurement, evidence for a causal relationship between institutional prestige and labor market outcomes remains ambiguous. Some US studies found significant positive earnings effects (Brewer et al. 1999; Hoekstra 2009; Loury and Garman 1995; Witteveen and Attewell 2017) or an advantage in occupational status (Brand and Halaby 2006) of the prestige of the institution attended, but other studies did not find effects on earnings (Dale and Krueger 2014; Dale and Krueger 2002; Long 2008). Similarly, for the UK, a few studies showed a wage premium of attending selective universities (Belfield et al. 2018; Broecke 2012; Chevalier and Conlon 2003; Hussain et al. 2009), but others were unable to detect differences in labor market outcomes (Sullivan et al. 2018a; Walker and Zhu 2018).

However, most existing studies relied on single snapshot measures of labor market outcomes and did not apply a longitudinal and dynamic perspective on how the prestige of the higher education institution attended shapes graduates' career progression (Gerber and Cheung 2008). Graduates from prestigious institutions may have an advantage in returns at labor market entry over graduates from non-prestigious institutions, but this advantage may decrease over time, remain stable, or even increase across the career. Studies that found no returns to college prestige at labor market entry also do not know whether returns emerge 
later in the career (Thomas and Zhang 2005). Differentiating between labor market entry and career progression also sheds light on the mechanisms for the effect of institutional prestige on labor market outcomes (Borgen 2014; Ishida et al. 1997). Suppose the advantages of graduates from prestigious institutions continue to exist beyond the initial stages of the career and assuming that productivity among graduates becomes more visible via their work experience. In that case, it will speak against the idea that the selectivity of the higher education institution is merely a signal for future productivity to employers. In recent years, scholars of social stratification increasingly used multilevel growth curve analysis - a more holistic approach of modeling occupational attainment over the life course - to examine interand intra-generational mobility simultaneously (Barone et al. 2011; Härkönen et al. 2016; Härkönen and Bihagen 2011; Manzoni et al. 2014; Passaretta et al. 2018; Schulz et al. 2015; Schulz and Maas 2010).

Besides notable exceptions (e.g., Borgen 2015; Dale and Krueger 2002), studies rarely address whether graduate characteristics such as attending different higher education institutions lead to varying labor market benefits for different socioeconomic groups. Whereas the relationship between family background and labor market destinations is weaker among graduates than among lower educated groups (Breen and Jonsson 2008; Hout 1988; Iannelli and Paterson 2007; Torche 2011), social inequalities at labor market entry among graduates are evident even after accounting for institutional prestige, the field of study or performance (Jacob et al. 2015; Triventi 2013). This suggests that other factors, such as parental resources or social networks, play a role in allocating graduates' labor market positions. Students from advantaged backgrounds may not only be more likely to enter prestigious universities (Boliver 2011; Jerrim et al. 2015), allocation to elite positions may act as a 'second filter' for family background, i.e., students from advantaged backgrounds 
have more resources to convert educational credentials into prestigious career paths (Rivera 2011).

The paper advances the literature in two significant ways. First, following recent advances in modeling careers across the life course, it investigates whether graduates from prestigious and less prestigious universities differ in their career progression across the early and mid-career stages. Second, it explores whether graduating from prestigious universities pays off more or less for graduates from different socioeconomic backgrounds and at what stages of the career. The empirical analysis draws on the 1970 British Cohort Study (BCS70) following the lives of individuals born in England, Scotland, and Wales in a single week of 1970. I model graduates' career progression from their first significant job until 14 years in the labor market. The BCS70 allows me to adjust for a rich set of covariates, including cognitive and non-cognitive ability measures that are commonly unavailable when accounting for selection into prestigious universities.

In what follows, I will first briefly discuss the theoretical considerations of why institutional prestige should matter for labor market outcomes. I further elaborate on why the effect of institutional prestige may vary across graduates from different family backgrounds before presenting data, methods, and empirical results.

\section{Institutional prestige and graduates' career trajectories}

Gerber and Cheung (2008: 301) differentiate between four theoretical explanations on why graduating from prestigious universities leads to higher labor market returns than graduating from non-prestigious universities: human capital theory, social networks, signaling theory, and selection bias.

From a human capital perspective, graduates from prestigious universities acquire advanced skills and knowledge during their studies that increase their labor market productivity. This may be, for instance, because of higher teaching quality and better support facilities at 
prestigious than at non-prestigious universities. In contrast, the level of skills and knowledge attained at prestigious universities is inaccessible to graduates from non-prestigious universities.

Apart from endowing their graduates with better skills, prestigious universities and their academic staff may be advantageous in providing access to top-level occupations because of their direct institutional links to employers or alumni networks (Ishida et al. 1997). This labor market advantage for graduates from prestigious universities may also come about through peer networks and informal personal ties among graduates from the same institution. Hence, graduates from prestigious universities profit from access to valuable social networks that provide links to top-level employers or information about job opportunities in the elite labor market that would otherwise be unavailable (Lee and Brinton 2006; Tholen et al. 2013). One example of how elite firms recruit graduates from prestigious universities is via on-campus recruitment programs (Rivera 2011).

According to signaling theory (Spence 1973), employers rely on asymmetric information when hiring labor market entrants and are unable to measure graduates' real productivity. To compensate for this, they use observable characteristics such as the institution's prestige to evaluate graduates' potential productivity (Morley and Aynsley 2007). Employers use graduate characteristics as a signal if the signaling costs - the investment costs for achieving a signal - are negatively correlated with individuals' productivity levels. If this were not the case, every individual would invest in this signal. Hence, employers assume that graduates from more prestigious universities are more productive than graduates from non-prestigious universities. They have this expectation regardless of whether graduates from prestigious universities become more productive during their education or whether they are more productive due to preexisting characteristics. The signaling value of the prestige of the institution attended may have increased during higher education expansion as access to 
prestigious institutions is more competitive and, at the same time, employers need to distinguish the most productive job candidates among an ever-increasing pool of graduates (Bills 2003; Jackson et al. 2005). Evidence suggests that elite firms receive a larger number of applications due to higher education expansion and, therefore, need to find ways to limit the number of suitable candidates (Rivera 2011; Tholen et al. 2013).

These theoretical considerations also help distinguish between the effects of the institutional prestige at labor market entry and later career progression. From a human capital point of view, one can expect that graduates from prestigious universities gain higher labor market returns than their peers from non-prestigious universities both at labor market entry and during career progression because real productivity differences between these groups exist. As employers may not appropriately assess the potential of graduates from prestigious universities at labor market entry, increasing effects of institutional prestige over graduates' careers are also in line with these assumptions.

Predicting the role of institutional networks in shaping the careers of graduates from prestigious universities is less straightforward. Institutional networks may provide advantages in access to elite occupations at any stage of the career. However, these networks may be more critical in the initial recruitment process than at later career stages. This is because elite employers approach new graduates directly at university and social ties to graduates, alumni, or staff at prestigious universities may loosen across the career. Assuming that institutional networks are the dominant mechanism behind the advantages of graduates from prestigious universities, the effect of institutional prestige later in the career should not be stronger than at labor market entry.

Since the signaling theory emphasizes the role of asymmetric information between employers and job candidates, the prestige of graduates' institution is a particularly relevant signal at labor market entry when information on graduates' real productivity level is unavailable 
(Arcidiacono et al. 2010; Ishida et al. 1997). Later in graduates' careers, employers can either evaluate their employees' productivity directly or use job candidates' work experience and previous accomplishments as more accurate signals for future productivity (Witteveen and Attewell 2017). Hence, if institutional prestige is associated with higher returns at labor market entry only, this would speak for the assumptions of signaling theory rather than the notion that prestigious universities provide graduates with skills, knowledge, and valuable networks in the long run.

Lastly, the positive association between graduating from prestigious universities and labor market returns may be due to selection bias. Students who attend prestigious universities are different regarding preexisting characteristics (e.g., family background, cognitive and noncognitive ability) from students who enroll in non-prestigious universities, and these characteristics are associated with higher labor market rewards. To estimate the effect of institutional prestige on labor market outcomes and shed light on the previously mentioned mechanisms, we need to address selection bias and condition on theoretically plausible confounders in the analysis. If selection bias were prevalent, we would not find any association between institutional prestige and labor market rewards neither at labor market entry nor during career progression.

The previous literature addressed selection bias by regression adjustment of observable confounders (e.g., Loury and Garman 1995), by exploiting college application data to account for unobserved endowments or ambitions (e.g., Dale and Krueger 2002), by applying sibling and twin fixed effects (e.g., Lindahl and Regnér 2005), or by conducting quasi-experimental designs such as instrumental variables (IV) estimation (e.g., Long 2008) and regression discontinuity designs (e.g., Hoekstra 2009). Analyzing college quality and hourly wages in Norway, Borgen (2014) compared estimates obtained from standard regression analysis to more sophisticated analytical techniques. He concluded that substantive results did not 
depend on the modeling approach, suggesting that adjusting for common observable confounders is sufficient to estimate the effect of university prestige on labor market outcomes (see also Long 2008).

\section{Returns to institutional prestige by family background}

Whether and to what extent institutional prestige is advantageous for initial labor market entry and career progression may depend on graduates' family background. To get access to advantageous occupational positions attending prestigious universities may be a necessary prerequisite, but in the end, it may not be sufficient to succeed. The positive selection hypothesis argues that students who are most likely to attend prestigious universities will benefit the most from it (Brand and Xie 2010). Since children from more advantaged socioeconomic backgrounds are more likely to attend prestigious universities than children from disadvantaged backgrounds (Boliver 2011; Jerrim et al. 2015), they may also have higher returns from attending these universities (Karabel and McClelland 1987). This is because graduates from higher socioeconomic backgrounds have more resources to convert educational credentials into prestigious career paths creating a 'second filter' on individuals' family background (Rivera 2011).

One mechanism by which this 'second filter' may manifest itself is via differential access to institutional networks (Tholen et al. 2013). Even though students from lower socioeconomic backgrounds managed to enter previous universities, they may be unsuccessful in establishing the social ties needed to harness advantages in access to elite occupations. In contrast, students from higher socioeconomic backgrounds can exploit these institutional ties either because they have wider pre-existing networks, including their parents, that make these networks accessible or because they have the social skills and the knowledge of how prestigious universities operate that help them to navigate the social environment (Hamilton et al. 2018). 
Another way graduates from higher socioeconomic backgrounds may be more able to convert graduation from prestigious universities into higher labor market returns is through characteristics linked to their upbringing (Erikson and Jonsson 1998). For instance, graduates from privileged backgrounds may have advanced social skills, soft skills, or manners that put them at an advantage in job application procedures in the elite job market. Furthermore, social skills and soft skills are increasingly demanded in higher managerial occupations as they involve diverse forms of 'people processing' (Jackson 2007; Jackson et al. 2005). Despite having graduated from a prestigious university, graduates from lower social backgrounds may be disadvantaged in gaining access to prestigious occupational positions due to their lack of social and soft skills.

Finally, graduates from prestigious universities that come from privileged backgrounds may have advantages in access to elite occupations simply because employers prefer job candidates that are culturally most similar to themselves (Erikson and Jonsson 1998; Jackson 2009). 'Cultural matching' (Rivera 2012) between elite employers and job candidates not only exists when both sides graduated from prestigious universities but also when they come from the same advanced classes of origin. Therefore, graduates from lower social backgrounds may be disadvantaged in gaining access to advanced occupational positions because they do not have the cultural resources (e.g., familiarity with elite activities, lifestyles and ways of communicating) to signal cultural proximity (Manzoni and Streib 2018; Walpole 2003).

The negative selection hypothesis argues that students who are least likely to attend prestigious universities will gain the highest returns (Brand and Xie 2010). Whereas the positive selection hypothesis assumes that graduating from prestigious universities is a prerequisite for obtaining access to advanced occupational positions, the negative selection hypothesis proposes that graduates from higher socioeconomic backgrounds have the 
necessary socio-cultural resources and knowledge to gain access to elite occupational positions even without educational credentials from prestigious universities (Hamilton 2016). In contrast, graduates from lower socioeconomic backgrounds lack these parental resources and can compensate for this lack by accessing resources via attending prestigious universities. Students from lower socioeconomic backgrounds attending prestigious universities gain the resources (e.g., social networks, cultural fit) that they, otherwise, would not have when competing with graduates from higher socioeconomic backgrounds from nonprestigious universities. Hence, attending prestigious universities is more beneficial for students from lower socioeconomic backgrounds than for their peers from higher socioeconomic backgrounds.

Evidence suggests that a degree is the "great equalizer" of socioeconomic inequality in labor market destinations (Chetty et al. 2017; Hout 1988; Karlson 2019; Torche 2011). Similarly, one could argue that a degree from prestigious universities further "equalizes" socioeconomic inequality as there is less leeway for parental influence when it comes to job allocation. This is because a degree from prestigious universities is a sufficient marker providing access to elite occupational positions irrespective of graduates' social background. In line with the negative selection hypothesis, social inequalities in occupational positions are smaller among graduates from prestigious universities than they are among graduates from non-prestigious universities. However, research evidence for the US is mixed. Whereas Giani (2016) found a smaller effect of social background on earnings among graduates from selective universities than among graduates from non-selective universities, others showed that the association between family background and wages is strongest among graduates of the least and mostselective universities (Manzoni and Streib 2018; Thompson 2019).

\section{Data and methods}


For the empirical analysis, I use the 1970 British Cohort Study (BCS70), which follows the lives of people born in England, Scotland, and Wales in a single week of 1970 (Elliott and Shepherd 2006). Data were collected at birth, age five, 10, 16, 26, and four-year intervals from 30 onwards. The latest sweep that is publicly available surveyed cohort members when they were aged 42. In this paper, I use the 1970 British Cohort Study Activity Histories dataset (University of London 2017), including retrospective information on activity histories from 16 until 42. I merged these data with information on background characteristics at age 10 (Butler and Bynner 2016) and retrospective information (secondary educational qualifications, the timing of graduation, the field of study, class of degree, type of degree) on educational careers from a dataset including the full histories of educational qualifications (Bukodi 2017). These data were further supplemented with retrospective information on other graduate characteristics (field of study, mode of study) and family formation from sweeps six to nine (age 30-42, University of London 2016a, 2016b, 2016c, 2016d). Crucially, at age 42 (sweep nine), the survey asked cohort members retrospectively about the higher education institution at which they gained their degree. Information on secondary school type is drawn from three different sources: the Head Teacher questionnaire in 1986, the School Census data in 1986 (Bynner et al. 2017), and a retrospective question put to the cohort member in $2012 .^{1}$ The analytical sample is restricted to individuals who graduated from a UK higher education institution until the age of 34 and were observed until 42. I do not consider any degree attainment after 34 because these individuals are a much more selective group, and they did not gain enough labor market experience in my observation period. However, I continue to observe the educational careers (another degree, postgraduate degree) until the age of 42 for those who graduated until age 34 .

\footnotetext{
${ }^{1}$ If only one source of information existed, I used this information. If there were several sources, the Head Teacher response was prioritized, followed by the School Census information and the retrospective response at 42.
} 
The dependent variable is the Standard International Occupational Prestige Scale (SIOPS) (Treiman 1977), which is a standard outcome measure in life course analyses of occupational attainment (Härkönen and Bihagen 2011; Härkönen, Manzoni and Bihagen 2016; Manzoni, Härkönen and Mayer 2014). Occupational prestige is defined as "the general level of social standing enjoyed by the incumbents of an occupation" (Hauser and Warren 1997, p. 188). It is stable over time and across countries (Hout and DiPrete 2006) and is also strongly correlated with other stratification measures such as the International Socio-Economic Index of Occupational Status (ISEI) and earnings growth (Lambert and Bihagen 2014). To assign SIOPS scores to occupations, I recoded British SOC90 occupational codes into ISCO-88 codes.

To observe graduates' career progression, I use monthly information on their occupational position since they started their first significant job (lasting at least six months). Following graduates for up to fourteen years since their labor market entry, this measure is rightcensored at 168 months and will be included in the modeling as seven 24-month splines. Using splines avoids predefining a functional form of the career and allows for variation in career progression across different stages without exploiting too many degrees of freedom. By estimating linear slopes for each range, splines avoid inappropriate jumps that would be prevalent in a simple dummy variable model (Marsh and Cormier 2002).

To operationalize the prestige of universities, I differentiate between Russell Group universities and other universities. The Russell Group was founded in 1994 and consists now of 24 research intensive UK universities. ${ }^{2}$ It has no official role, but membership is an indicator of institutional status in the public and policy discourse. Russell Group Universities

\footnotetext{
${ }^{2}$ Birmingham, Bristol, Cambridge, Cardiff, Durham, Edinburgh, Exeter, Glasgow, Imperial College London, King's College London, Leeds, Liverpool, London School of Economics \& Political Science, Manchester, Newcastle, Nottingham, Oxford, Queen Mary, University of London, Belfast, Sheffield, Southampton, University College London, Warwick, York.
} 
represent themselves as the 'jewels in the crown' of the higher education system (Russell Group 2012). Admission to Russell Group Universities is highly selective: private schooling, high entry grades, and an advanced social background are the strongest predictors of enrolment into Russell Group universities (Boliver 2011, 2013; Hemsley-Brown 2015). This institutional differentiation by selectivity appears to be remarkably stable over time (Raffe and Croxford 2015). Apart from their selective student composition, Russell Group universities rank higher on quality, at least when it comes to pupil-staff ratio, research assessment, and academic expenditures per student (Chevalier 2014; Chevalier and Conlon 2003).

To account for selection into prestigious universities, I adjust the analysis with several important confounders. As students' endowments influence both the choice of university and labor market success, I condition on cognitive ability, non-cognitive skills, and highest academic secondary qualification attained. Following Breen and Goldthorpe (2001) and Connelly and Gayle (2019), I measure cognitive ability at age ten by totaling all four conducted British Ability Scales (BAS) assessments (Elliott, Murray and Pearson 1979) two verbal subscales (word definitions and word similarities) and two non-verbal subscales (recall of digits and matrices) - and standardize it to a mean of 100 and a standard deviation of $15 .^{3}$

To operationalize non-cognitive skills I use the psychosocial measure of locus of control at age ten. It refers to the degree to which individuals perceive themselves as able to decide over and manage their destiny (internal) rather than other forces (external). In the BCS70, cohort members at age ten filled in the CARALOC questionnaire (Gammage 1982), a general locus of control measure developed specifically for children that closely mirrors the often-used locus of control test by Nowicki and Strickland (1973). Raw scores range from zero to 15,

\footnotetext{
${ }^{3}$ Alternatively, I could have used principal component analysis (PCA) to create a measure of general ability ' $\mathrm{g}$ '. However, Connelly and Gayle (2019) showed that the total scores and scores derived from PCA are almost perfectly correlated.
} 
where high scores indicate greater internalization. The measure is standardized to have a mean equal to zero and a standard deviation equal to one.

Regarding the highest secondary qualification attained, I differentiate between three categories: "lower secondary education", "1 A-level (higher secondary - low performance)", and "2+ A-levels (higher secondary - high performance)". Since 2+ A-levels are a common requirement for entry to higher education, graduates with qualifications below this threshold have followed non-standard pathways to university.

Another important confounder to address is the family background. Students from advantaged socioeconomic backgrounds are overrepresented in Russell Group universities (Boliver, 2011, 2013). At the same time, graduates from a higher-class background gain advanced labor market returns, possibly via accessing parental resources (Jacob et al. 2015). Therefore, the analysis includes measures of parental education and parental class at age 10 . Regarding parental education, I differentiate between continuing-generation graduates and first-generation graduates, i.e., between graduates with at least one parent with a degree and those with parents who did not attain a degree.

Parental class is operationalized with the National Statistics Socio-Economic Classification (NS-SEC). To construct NS-SEC codes, I rely on additional occupational coding provided by Gregg (2012). I follow the 'dominance principle' using the highest class position among both parents and differentiating three classes: salariat class (higher and lower managerial and professional occupations), intermediate class (intermediate occupations, small employers and own account workers, lower supervisory and technical occupations) and working class (semiroutine and routine occupations).

Private and grammar schooling are strong determinants of admission to Russell Group universities (Hemsley-Brown 2015; Sullivan et al. 2014) and labor market outcomes (Dearden et al. 2002; Green et al. 2018). I distinguish between the following secondary 
school types: private, grammar (state academically selective schools), secondary modern (state schools for students not selected into grammar schools), and comprehensive (all-ability state schools). The analyses also account for gender and ethnic origin (graduates born in the UK vs. graduates originating from abroad).

Apart from covariates that account for selection into prestigious universities, I also control for graduate characteristics such as field of study, type of degree, class of degree, and study mode. This is because I made theoretical predictions of labor market returns to institutional prestige net of the student population's compositional differences. Prestigious universities may differ from other universities regarding student take-up of more beneficial fields of study, a higher share of full-time students, higher grades on average, or facilitated pathways into postgraduate attainment. In turn, these factors may be associated with higher labor market returns. To operationalize the field of study, I differentiate between three broad groups: 1) humanities (incl. arts), 2) social sciences (incl. economics and business, law and medicine), and 3) fields in STEM (science, technology, engineering, and mathematics). The type of degree differentiates between first degree and postgraduate degree. The study mode is measured with two categories: full-time vs. part-time studies. All these measures are timevarying, i.e. they may change across graduate careers. The class of degree consists of the following categories: obtaining a (1) first-class honors, a (2) 2:1 (upper second-class honors), a (3) 2:2 (lower second-class honors) and a (4) third (third-class honors) or pass.

In line with a life course perspective, the measure of career progression captures the time since individuals entered the labor market rather than their actual work experience. Hence, it does not account for career circumstances, career breaks, and re-entry into the labor market due to family formation. Therefore, I also adjust the analysis with time-varying measures for part-time employment, the number of children, and marital status (single, married, divorced). 
Family circumstances are correlated with the type of university and yield different labor market returns (Walker and Zhu 2018).

To analyze the association between institutional prestige and occupational attainment across the life course, I use multilevel growth curve modeling (Halaby 2003; Steele 2008). Researchers increasingly applied this method when modeling career progression over time (Barone et al. 2011; Härkönen et al. 2016; Härkönen and Bihagen 2011; Manzoni et al. 2014; Passaretta et al. 2018; Schulz et al. 2015; Schulz and Maas 2012). Following an unbalanced panel data structure, I restructured the data into a person-month format. Using random effects (RE) panel regression models allows me to estimate coefficients for time-constant (above all, institutional prestige) and time-varying variables (e.g., postgraduate attainment or the number of children). Growth curve analysis emphasizes the modeling of time and, in this paper, on the interaction between covariates of interest and time modelling differences in career progression by institutional prestige.

The baseline growth curve model is as follows:

$$
\begin{aligned}
& y_{i t}=\beta_{0}+\sum_{k=1}^{7} \beta_{1 k} \text { Time }_{i t k}+\beta_{2} \text { Russ }_{i}+\sum_{l=1}^{8} \beta_{3 i} \text { Select }_{i l}+\sum_{m=1}^{4} \beta_{4 m} \text { Grad }_{i(t) m}+ \\
& \sum_{j=3}^{3} \beta_{5 j} \text { Fam }_{i t j}+\mu_{i}+\varepsilon_{i t}
\end{aligned}
$$

The model includes the seven 24-months splines, a dummy variable differentiating between graduates from Russell Group and other universities, eight time-constant variables accounting for selection, four time-constant and time-varying variables controlling for other graduate characteristics, three time-varying variables adjusting for family formation, a person-specific unobserved factor $\mu$ (random effect) and a time-varying error term $\varepsilon$. The intraclass correlation - which is calculated based on the variances of the error terms $\left(\rho=\sigma_{\mu}^{2} /\left(\sigma_{\mu}^{2}+\sigma_{\varepsilon}^{2}\right)\right)$ - indicates how much of the overall variance in occupational prestige is due to variation between individuals and variation within individuals across the early and 
mid-career. The stronger this intraclass correlation, the more inequality between graduates in occupational prestige exists, and the fewer within-changes occur across graduate careers.

The $\beta_{1 k}$ estimates show the average monthly change in occupational prestige within each of the 24-month splines. The remaining $\beta$ coefficients indicate the strength of associations between the respective variables and occupational prestige averaged across the early working career. To analyze whether graduates from Russell Group and other universities differ regarding career progression, I extend this baseline model by including interaction terms between the Russell Group indicator and the seven splines. Finally, I will estimate this extended model separately for first-generation graduates and continuing-generation graduates to test the negative vs. positive selection hypothesis.

The BCS70 is affected by considerable unit non-response across all waves. Only around 20 percent of cohort members participated in all existing waves, over half of the cohort members dropped out of at least one wave but returned to the study, and one third dropped entirely (Mostafa and Wiggins 2015). To correct for non-random loss to follow-up, I estimated the inverse probability of attrition weights (Hernán et al. 2000). The attrition weight $a w$ is formally defined as the ratio of the unconditional probability that a respondent $i$ is observed until age 42 (the latest sweep I use information from) and the same probability conditional on covariates $\mathrm{Z}$ measured at age 10. As probabilities are unknown, they are estimated via logistic regression (see Tables S1 and S2 in the Supplementary Material for the model estimating the denominator and summary statistics for the censoring weight).

$$
a w_{i}=\frac{P\left(a_{i}=0\right)}{P\left(a_{i}=0 \mid z_{i}\right)}
$$


Weighting the sample creates a pseudo-population in which loss to follow-up is independent of the variables included in the prediction model, thus avoiding bias from systematic attrition based on the observed variables.

\section{Results}

Table 1 provides an overview of the variables and descriptive statistics for 939 complete cases with 135,962 person-months. In this sample of graduates, SIOPS scores range between 15 (e.g., building construction laborers) and 78 (e.g., university professors and medical doctors), with an average of 55.33 and a standard deviation of 11.35. The average time I observe graduates since their first significant job is almost seven years ( $\mathrm{SD}=48.26$ months). One-third of graduates obtained their degree from Russell Group universities. The overwhelming majority of graduates studied full-time (94\%). Social sciences were the most common discipline (40\%), followed by STEM fields (32\%) and humanities (28\%). Whereas the percentage of graduates from a working-class background is small (11\%), almost half of the graduates $(47 \%)$ originate from a household where neither parents obtained a degree. $28 \%$ of first-generation students graduate from Russell Group universities compared to $40 \%$ of continuing-generation students (see Appendix Table S3 for summary statistics of all variables by parental education). Two-thirds of graduates gained more than two A-levels during their secondary schooling and attended comprehensive schooling.

\section{Table 1 here}

Table 2 introduces several growth curve models. The zero model (M0) is an empty model without any covariates and decomposes the total variance into variance between individuals and within-variance across the career. Model M1 includes seven 24-month splines and indicates how occupational prestige, on average, changes across 14 years since graduates had 
their first significant job. The second model (M2) introduces our primary independent variable differentiating between graduates from Russell Group universities and other universities. Model M3 accounts for selection into prestigious universities holding information on cognitive ability, non-cognitive ability, parental education, parental class, gender, ethnicity, secondary school qualifications, and the type of secondary schooling constant. The fourth model (M4) additionally adjust for graduate characteristics (the type of degree, field of study, class of degree, mode of study). Finally, the fifth model (M5) includes information adjusting for family formation. Estimates for control variables are not shown in table 1 and are included in table S4 in the Supplementary Material. The empty model provides an estimate for the intraclass correlation coefficient (ICT) indicating the extent to which the total variation in occupational prestige is due to differences between graduates rather than within-differences across the career. In this sample, the ICT shows that 68 percent of the overall variance is due to occupational prestige differences between graduates. Hence, more inequality in occupational attainment varies between graduates than it varies over careers, suggesting a strong role of the first significant job for life-course occupational attainment.

\section{Table 2 here}

Model 1 in Table 2 shows that graduates' career progression predominantly took place in the first two years after gaining their first significant job. The average graduate gained $3.48(24 \mathrm{x}$ 0.145) SIOPS points across the first two years. Over the following four years, career progression slowed markedly down $(24 \times 0.028+24 \times 0.020=1.15$ SIOPS points $)$, speeded up again in years six to eight since labor market entry $(24 \times 0.041=0.98$ SIOPS points $)$ and was very limited in the last six years of the observation period $(24 \times 0.017+24 \times 0.013+24$ x $0.00=0.72$ SIOPS points). Overall, graduates gained, on average, 6.33 SIOPS points across 14 years since their first significant job. 
The second model shows that graduates from Russell Group universities had, on average, an advantage of 2.40 SIOPS points over graduates from other universities. Adjusting for selection into prestigious universities strongly reduced the estimate to 1.56 SIOPS points in the third model. Accounting for graduate characteristics and family formation across the working career further reduced the estimate but only to a limited extent. As expected, variables addressing selection are more substantive confounders than horizontal $\mathrm{HE}$ characteristics or family circumstances when estimating the effect of institutional prestige on occupational prestige. Overall, there was an advantage of graduating from Russell Group universities regarding occupational prestige after adjusting for confounders (1.13 SIOPS points), but this advantage is rather small and statistically non-significant.

Estimates in Table 2 refer to average careers and do not model career progression by institutional prestige. Table S5 in the Supplementary Material shows the estimates from a model, including interaction terms between institutional prestige and the seven 24-month splines. Figure 1 illustrates the predicted growth curves for graduates from Russell Group universities and other universities. It indicates small occupational prestige differences between graduates from Russell Group and other universities at labor market entry. This difference became slightly stronger across the first two years as graduates from Russell Group universities had steeper growth curves than those from other universities. In the following four years, growth curves ran in parallel, i.e., occupational prestige differences between both groups remained constant. After six years in the labor market, growth curves were somewhat steeper for graduates from other universities than for graduates from Russell Group universities. At the end of the observation period, there was hardly any difference in occupational prestige between graduates from universities with varying prestige levels. While occupational prestige differences by university type varied across the career, neither the main 
effect of university type nor the interaction terms with the 24-month splines were statistically significant at conventional criteria (see Table S5 in the Supplementary Material). ${ }^{4}$

\section{Figure 1 here}

To test the negative vs. positive selection hypothesis, I predicted SIOPS scores by institutional prestige and time since labor market entry for continuing-generation graduates (whose parents have at least one degree) and first-generation graduates (whose parents have no degree) separately. Figure 2 illustrates these growth curves (see full models in Table S6 in the Supplementary Material). Among first-generation graduates, there were no prestige differences by type of university at labor market entry. However, graduates from Russell Group universities had a much steeper growth curve than graduates from other universities in the first two years since their first significant job (the interaction term between the type of university and this spline is statistically significant, see model M7 in table S6). Among this group, prestige differences between Russell Group and other universities' graduates were largest after six years in the labor market (more than two SIOPS points). Graduates from other universities caught up in occupational prestige with their peers from Russell Group universities from then onwards. At the end of the observation period, there was no difference in occupational prestige by university type for first-generation graduates.

\section{Figure 2 here}

Among continuing-generation graduates, there was no consistent pattern of occupational prestige differences between graduates from Russell Group and other universities across the observation period. Whereas graduates from Russell Group universities had a small

\footnotetext{
${ }^{4}$ As a robustness check, I tested a multilevel growth curve model including random slopes for the spline variables. Running these models did not change the substantive conclusions regarding university type and career trajectories (see Figure S1 in the Supplementary Material). I also tested a model excluding job spells for graduates who obtained a postgraduate degree. This also does not change the results (see Figure S2 in the Supplementary Material).
} 
advantage over graduates from other universities at labor market entry, this advantage peaked at four and six years. As with graduates from lower educational backgrounds, graduates from more and less prestigious universities did not differ in occupational prestige after 14 years since labor market entry. Overall, the Russell Group premium was much smaller among continuing-generation graduates than among first-generation graduates.

\section{Discussion}

This paper investigated the association between institutional prestige (Russell Group universities vs. other universities) and graduates' career progression by parental education. It contributes to the literature by following graduates up to 14 years in the labor market, thereby assessing at what point in the career graduates from prestigious and non-prestigious universities differ in their occupational returns. Considering a dynamic and holistic account of graduates' career progression provides insights into why (prestigious) educational attainment yields returns in the labor market. Aside from this advantage, the British Cohort Study (BCS70) further allowed me to condition on early childhood covariates commonly unavailable in graduate surveys (e.g., cognitive ability or locus of control). The results on effect heterogeneity by parental education also inform the debate on the hypothesis of negative vs. positive selection in higher education, i.e., whether those who gain most or least access to prestigious universities profit more from elite education.

The findings show no discernible differences in occupational prestige between graduates from Russell Group universities and other universities once conditioning on covariates. When considering career trajectories, graduates from Russell Group universities had no advantages at immediate labor market entry but gained somewhat higher occupational prestige levels than students from other universities in the first two years since their first significant job. This advantage remained stable until their sixth year in the labor market. After six years in the labor market, however, graduates from other universities had a steeper 
career progression and caught up with their peers from Russell Group universities. Hence, if at all, there was a small premium for attending prestigious universities restricted to the early working career. These findings are broadly in line with Thomas and Zhang (2005) for the US and studies for Norway (Borgen and Mastekaasa 2018, Borgen 2014). Ishida et al. (1997) found that college quality mainly benefits individuals at the stages of recruitment in Japan, albeit restricted to the financial and insurance sector.

When analyzing graduates' career progression by parental education, I found some evidence for the negative selection hypothesis. Attending Russell Group universities paid off in the early stages of the career only for first-generation graduates. Those graduating from Russell Group universities had a steeper career progression in the first six years since their first significant job than graduates with the same background who attended other universities. Among continuing-generation graduates, the prestige of the university did not matter for career progression. These results align with other studies supporting the negative selection hypothesis for returns to university (Brand and Xie 2010) and returns to prestigious universities in the US (Dale and Krueger 2002; Zhang 2005). For Norway, Borgen (2015) found evidence for the positive selection hypothesis when considering parental earnings but not with parental education. Chevalier and Conlon (2003) did not find variation in the Russell Group wage premium across different family backgrounds in the UK, but their study was restricted to a single point in time.

The paper has several important caveats that need to be considered when interpreting the results. First, the analysis relies on a rather small number of observations, especially when considering the effect modification by parental education. For instance, the main effect of institutional prestige and the interaction terms with the seven 24-month splines are statistically non-significant at conventional criteria (see Appendix Table S5). The study may 
not have had enough statistical power to reject the null hypothesis of no occupational prestige differences between graduates from Russell Group universities and other universities.

Second, the small sample size did not allow me to differentiate prestige levels within the group of Russell Group universities. It may very well be that graduates from Oxbridge and London institutions (also known as the 'golden triangle') have a steeper career progression than graduates from the rest of the Russell Group. Hence, I may underestimate the occupational premium for institutional prestige.

Third, I was unable to investigate whether career trajectories by institutional prestige vary across degree levels (Torche, 2011, 2018; Oh and Kim, 2020) or different fields of study. Graduating from Russell Group universities may be particularly valuable in fields of study that yield lower labor market returns. There is, indeed, evidence showing that graduating from prestigious institutions is associated with different labor market outcomes depending on the field of study (Borgen and Mastekaasa 2018; Sullivan et al. 2018b; Walker and Zhu 2018).

Fourth, male and female graduates enter different partial labor markets in which employers may rely more or less on graduate characteristics such as the university type in their hiring and promotion decisions. Social and cultural capital acquired in elite institutions may be particularly beneficial in access to and promotion in services and higher managerial positions (Jackson, Goldthorpe and Mills 2005). Hence, it would have been important to investigate whether the association between institutional quality and occupational prestige trajectories varies by gender.

Fifth, causal interpretations of the Russell Group estimates rest on the unverifiable assumption that there are no (strong) unmeasured confounders. The analyses conditioned on important confounders such as family background, type of schooling, or cognitive ability at age ten. Nevertheless, students graduating from universities with different prestige levels may 
differ in significant dimensions not accounted for in the analysis. For instance, students attending prestigious universities may be more ambitious than students attending other universities, and, in turn, ambition may be rewarded in the labor market.

Sixth, the paper investigated the relation between university type and occupational trajectories but did not consider within-occupation changes in returns to university prestige. Career trajectories for graduates from Russell Group and other universities may be different from the present analysis when using wages as the key outcome. Wages may be less prone to ceiling effects than occupational outcomes when focusing on a sample of graduates.

Assuming that these caveats are not pivotal, the results provide neither evidence for the signaling theory nor the human capital theory. Since graduates from Russell Group universities did not have advantages over other graduates in their first significant job, employers do not seem to rely on institutional quality as a screening device when they lack information about graduates' real productivity. The findings are also at odds with the human capital theory predictions because the somewhat increasing Russell Wage premium across the early working career does not persist in later stages. If graduating from prestigious universities increases individuals' productivity, employers learn about their productivity when graduates gain work experience and reward them at any stage of their working life. The non-existence of a Russell Group Premium in later stages of the career also speaks against the idea that graduates from Russell Group universities sort into initial jobs with better long-term occupational trajectories.

It appears that any small advantages graduates from Russell Group universities may have are limited to the early occupational career. Graduates from other universities quickly catch up with graduates from prestigious universities and achieve the same occupational prestige levels. This early Russell Group premium is also limited to first-generation graduates providing support for the negative selection hypothesis. Graduates from higher educational 
backgrounds have similar occupational trajectories irrespective of whether they graduate from prestigious universities or not. First-generation graduates can only compete with graduates from advantaged backgrounds in the career's initial stages if they attended a Russell Group university. This suggests that the disadvantages of first-generation graduates from other universities are due to resources, e.g., social networks or opportunity structures, e.g., managerial and professional job opportunities in the geographical area, that are restricted without elite education. Nevertheless, also first-generation graduates from other universities catch up with graduates from prestigious universities across the working career. It just takes them longer to achieve the same occupational prestige as their peers with an elite education.

Evidence for the negative selection hypothesis - at least in the early occupational career - suggests that similar to a degree (Karlson 2019; Torche 2011), prestigious university education has the power to foster intergenerational social mobility. Students whose parents do not have a degree and who are least likely to go to prestigious universities profit the most from it regarding occupational positions and, as such, are less disadvantaged compared to students from higher educational backgrounds than their peers at less prestigious universities. Hence, widening access to prestigious universities for students from disadvantaged backgrounds may be an effective way of improving intergenerational fluidity in the UK.

Future research needs to replicate these results on institutional prestige and career progression with larger graduate samples and different outcomes, for instance, wages. Furthermore, the present paper was unable to disentangle the possible explanations for the negative selection hypothesis, i.e., why graduating from Russell Group universities pays off for graduates from lower educational backgrounds only. It remains open to future research to test potential mechanisms for the heterogeneous career patterns I observed. 


\section{References}

Arcidiacono, P., Bayer, P., \& Hizmo, A. (2010). Beyond signaling and human capital: Education and the revelation of ability. American Economic Journal: Applied Economics, 2(4), 76-104.

Barone, C., Lucchini, M., \& Schizzerotto, A. (2011). Career Mobility in Italy. European Societies, 13(3), 377-400.

Belfield, C., Britton, J., Buscha, F., Dearden, L., Dickson, M., Van Der Erve, L., et al. (2018). The relative labour market returns to different degrees. Institute for Fiscal Studies: Research Report.

Bills, D. B. (2003). Credentials, Signals, and Screens: Explaining the Relationship between Schooling and Job Assignment. Review of Educational Research, 73(4), 441-469.

Boliver, V. (2011). Expansion, differentiation, and the persistence of social class inequalities in British higher education. Higher Education, 61(3), 229-242.

Boliver, V. (2013). How Fair Is Access to More Prestigious UK universities. British Journal of Sociology, 64(2), 344-364.

Borgen, N. T. (2014). College Quality and Hourly Wages: Evidence from the Self-revelation Model, Sibling Models and Instrumental Variables. Social Science Research, 48, 121-134.

Borgen, N. T. (2015). College quality and the positive selection hypothesis: The "second fiter" on family background in high-paid jobs. Research in Social Stratification and Mobility, $39,32-47$.

Borgen, N. T., \& Mastekaasa, A. (2018). Horizontal Stratification of Higher Education: The Relative Importance of Field of Study, Institution, and Department for Candidates' Wages. Social Forces, 97(2), 531-558.

Brand, J. E., \& Halaby, C. N. (2006). Regression and matching estimates of the effects of elite college attendance on educational and career achievement. Social Science Research, 35(3), 749-770.

Brand, J. E., \& Xie, Y. (2010). Who Benefits Most from College? American Sociological Review, 75(2), 273-302.

Breen, R., \& Jonsson, J. O. (2008). Explaining Change in Social Fluidity: Educational Equalization and Educational Expansion in Twentieth-Century Sweden. American Journal of Sociology, 112(6), 1775-1810.

Brewer, D. J., Eide, E. R., \& Ehrenberg, R. G. (1999). Does it pay to attend an elite private college? Cross-cohort evidence on the effects of college type on earnings. Journal of Human Resources, 34(1), 104-123.

Broecke, S. (2012). University selectivity and earnings: Evidence from UK data on applications and admissions to university. Economics of Education Review, 31(3), 96-107.

Bukodi, E. (2017). National Child Development Study and 1970 British Cohort Study Educational Qualifications Histories, 1981-2009. [data collection]. University of London, Institute of Education, Centre for Longitudinal Studies, [original data producer(s)]. University of London, Institute of Education, Centre for Longitudinal Studies. SN: 8127, http://doi.org/10.5255/UKDA-SN-8127-1

Butler, N., Bynner, J.M. 2016 University of London. Institute of Education. Centre for Longitudinal Studies. 1970 British Cohort Study: Ten-Year Follow-Up, 1980. [data collection]. 6th Edition. UK Data Service. SN: 3723, http://doi.org/10.5255/UKDA-SN-3723$\underline{7}$

Bynner, J., University of London. Institute of Education. Centre for Longitudinal Studies, Butler, N. (2017). 1970 British Cohort Study: Sixteen-Year Follow-Upm, 1986. [data collection]. 7th Edition. UK Data Service. SN: 3535, http://doi.org/10.5255/UKDA-SN-35354 
Chetty, R., Friedman, J., Saez, E., Turner, N., \& Yagan, D. (2017). Mobility Report Cards: The Role of Colleges in Intergenerational Mobility. NBER Working Paper, No. 23618.

Chevalier, A. (2014). Does higher education quality matter in the UK? Research in Labor Economics, 40.

Chevalier, A., \& Conlon, G. (2003). Does It Pay to Attend a Prestigious University? IZA Discussion Paper, 848, 1-32.

Connelly, R., \& Gayle, V. (2019). An investigation of social class inequalities in general cognitive ability in two British birth cohorts. British Journal of Sociology, 70(1), 90-108.

Dale, S. B., \& Krueger, A. B. (2002). Estimating the payoff to attending a more selective college: An application of selection on observables and unobservables. Quarterly Journal of Economics, 117(4), 1491-1527.

Dale, S. B., \& Krueger, A. B. (2014). Estimating the effects of college characteristics over the career using administrative earnings data. Journal of Human Resources, 49(2), 323-358.

Dearden, L., Ferri, J., \& Meghir, C. (2002). The effect of school quality on educational attainment and wages. Review of Economics and Statistics, 84(1), 1-20.

Elliott, J., \& Shepherd, P. (2006). Cohort profile: 1970 British Birth Cohort (BCS70). International Journal of Epidemiology, 35(4), 836-843.

Erikson, R., \& Jonsson, J. O. (1998). Social Origin as an Interest-bearing Asset: Family Background and Labour-market Rewards among Employees in Sweden. Acta Sociologica, 41, 19-36.

Gammage, P. (1982). Children and Schooling: Issues in Childhood Socialisation. London: George Allen and Unwin.

Gerber, T. P., \& Cheung, S. Y. (2008). Horizontal Stratification in Postsecondary Education: Forms, Explanations, and Implications. Annual Review of Sociology, 34, 299-318.

Giani, M. S. (2016). Are All Colleges Equally Equalizing?: How Institutional Selectivity Impacts Socioeconomic Disparities in Graduates' Labour Market Outcomes. The Review of Higher Education, 39(3), 431-461.

Green, F., Parsons, S., Sullivan, A., \& Wiggins, R. (2018). Dreaming big? Self-valuations, aspirations, networks and the private-school earnings premium. Cambridge Journal of Economics, 42(3), 757-778.

Gregg, P. (2012). Occupational Coding for the National Child Development Study (1969, 1991-2008) and the 1970 British Cohort Study (1980, 2000-2008). University of London. Institute of Education, Centre for Longitudinal Studies, [original data producer(s)]. University of London, Institute for Education, Centre for Longitudinal Studies. SN: 7023, http://doi.org/10.5255/UKDA-SN-7023-1

Hamilton, L. (2016). Parenting to a Degree. Chicago: Chicago University Press.

Hamilton, L., Roksa, J., \& Nielsen, K. (2018). Providing a “Leg Up”': Parental Involvement and Opportunity Hoarding in College. Sociology of Education, 91(2), 111-131.

Härkönen, J., \& Bihagen, E. (2011). Occupational Attainment and Career Progression in Sweden. European Societies, 13, 451-479.

Härkönen, J., Manzoni, A., \& Bihagen, E. (2016). Gender inequalities in occupational prestige across the working life: An analysis of the careers of West Germans and Swedes born from the 1920s to the 1970s. Advances in Life Course Research, 29, 41-51.

Hemsley-Brown, J. (2015). Getting into a Russell Group university: High scores and private schooling. British Educational Research Journal, 41(3), 398-422.

Hernán, M., Brumback, B., \& Robins, J. M. (2000). Marginal structural models and causal inference in epidemiology. Epidemiology, 11(5), 550-60.

Hoekstra, M. (2009). The effect of attending the flagship state university on earning: A discontinuity approach. Review of Economics and Statistics, 91(4), 717-724.

Hout, M. (1988). More Universalism, Less Structural Mobility: The American Occupational 
Structure in the 1980s. American Journal of Sociology, 93, 1358-1400.

Hout, M., \& DiPrete, T. A. (2006). What we have learned: RC28's contributions to knowledge about social stratification. Research in Social Stratification and Mobility, 24(1), $1-20$.

Hussain, I., McNally, S., \& Shqiponja, T. (2009). University Quality and Graduate Wages in the UK. IZA Discussion Paper (Vol. No. 4043). Institute for the Study of Labor (IZA).

Iannelli, C., \& Paterson, L. (2007). Education and Social Mobility in Scotland. Research in Social Stratification and Mobility, 25, 219-232.

Ishida, H., Spilerman, S., \& Su, K.-H. (1997). Educational Credentials and Promotion Chances in Japanese and American Organizations. American Sociological Review, 62(6), 866-882.

Jackson, M. (2007). How Far Merit Selection? Social Stratification and the Labour Market. British Journal of Sociology, 58(3), 367-390.

Jackson, M. (2009). Disadvantaged through Discrimination? The Role of Employers in Social Stratification. British Journal of Sociology, 60(4), 669-691.

Jackson, M., Goldthorpe, J. H., \& Mills, C. (2005). Education, Employers and Class Mobility. Research in Social Stratification and Mobility, 23, 3-33.

Jacob, M., Klein, M., \& Iannelli, C. (2015). The Impact of Social Origin on Graduates' Early Occupational Destinations - An Anglo-German Comparison. European Sociological Review, $31(4), 460-476$.

Jerrim, J., Chmielewski, A. K., \& Parker, P. (2015). Socioeconomic Inequality in Access to High-Status Colleges: A Cross-Country Comparison. Research in Social Stratification and Mobility, 42, 20-32.

Karabel, J., \& McClelland, K. (1987). Occupational Advantage and the Impact of College Rank on Labor Market Outcomes. Sociological Inquiry, 57(4), 323-347.

Karlson, K. B. (2019). College as Equalizer? Testing the selectivity hypothesis. Social Science Research, 80, 216-229.

Lambert, P., \& Bihagen, E. (2014). Using occupation-based social classifications. Work, Employment and Society, 28(3), 481-494.

Lee, S., \& Brinton, M. C. (2006). Elite Education and Social Capital: The Case of South Korea. Sociology of Education.

Lindahl, L., \& Regnér, H. (2005). College choice and subsequent earnings: Results using Swedish sibling data. Scandinavian Journal of Economics, 107(3), 437-457.

Long, M. C. (2008). College quality and early adult outcomes. Economics of Education Review, 27(5), 588-602.

Loury, L. D., \& Garman, D. (1995). College Selectivity and Earnings. Journal of Labor Economics. doi:10.1086/298375

Manzoni, A., Härkönen, J., \& Mayer, K. U. (2014). Moving On? A Growth-Curve Analysis of Occupational Attainment and Career Progression Patterns in West Germany. Social Forces, 92(4), 1285-1312.

Manzoni, A., \& Streib, J. (2018). The Equalizing Power of a College Degree for FirstGeneration College Students: Disparities Across Institutions, Majors, and Achievement Levels. Research in Higher Education, https://doi.org/10.1007/s11162-018-9523-1.

Marsh, L. C., \& Cormier, D. R. (2002). Spline Regression Models, vol. 137. Thousand Oaks, CA: Sage.

Morley, L., \& Aynsley, S. (2007). Employers, quality and standards in higher education: Shared values and vocabularies or elitism and inequalities? Higher Education Quarterly, 61(3), 229-249.

Nowicki, S., \& Strickland, B. R. (1973). A locus of control scale for children. Journal of Consulting and Clinical Psychology, 40(1), 148-154. 
Oh, B., \& Kim, C. (2020). Broken promise of college? New educational sorting mechanisms for intergenerational association in the 21st century. Social Science Research, 86, 102375.

Passaretta, G., Barbieri, P., Wolbers, M. H. J., \& Visser, M. (2018). The direct effect of social origin on men's occupational attainment over the early life course: An Italian-Dutch comparison. Research in Social Stratification and Mobility, 56, 1-11.

Raffe, D., \& Croxford, L. (2015). How stable is the stratification of higher education in England and Scotland? British Journal of Sociology of Education, 36(2), 313-335.

Rivera, L. A. (2011). Ivies, extracurriculars, and exclusion: Elite employers' use of educational credentials. Research in Social Stratification and Mobility, 29, 71-90.

Rivera, L. A. (2012). Hiring as Cultural Matching: The Case of Elite Professional Service Firms. American Sociological Review, 77(6), 999-1022.

Russell Group. (2012). Jewels in the crown: The importance and characteristics of the UK's world-class universities. London: Russell Group.

Schulz, W., \& Maas, I. (2010). Studying Historical Occupational Careers with Multilevel Growth Models. Demographic Research, 23, 669-696.

Schulz, W., \& Maas, I. (2012). Studying Career Success - The Role of Resources and Norms for Occupational Status Attainment in The Netherlands, 1865-1940. European Sociological Review, 28(2), 220-240.

Schulz, W., Maas, I., \& van Leeuwen, M. H. D. (2015). Occupational career attainment during modernization. A study of Dutch men in 841 municipalities between 1865 and 1928 . Acta Sociologica, 58(1), 5-24.

Spence, M. (1973). Job Market Signaling. The Quarterly Journal of Economics, 87(3), 355374. doi: $10.2307 / 1882010$

Sullivan, A., Parsons, S., Green, F., Wiggins, R. D., \& Ploubidis, G. (2018a). The path from social origins to top jobs: social reproduction via education. British Journal of Sociology, 69(3), 776-798.

Sullivan, A., Parsons, S., Green, F., Wiggins, R. D., \& Ploubidis, G. (2018b). Elite universities, fields of study and top salaries: Which degree will make you rich? British Educational Research Journal, 44(4), 663-680.

Sullivan, A., Parsons, S., Wiggins, R., Heath, A., \& Green, F. (2014). Social origins, School Type and Higher Education Destinations. Oxford Review of Education, 40(6), 739-763.

Tholen, G., Brown, P., Power, S., \& Allouch, A. (2013). The Role of Networks and Connections in Educational Elites' Labour Market Entrance. Research in Social Stratification and Mobility, 34, 142-154.

Thomas, S. L., \& Zhang, L. (2005). Post-baccalaureate wage growth within four years of graduation: The effects of college quality and college major. Research in Higher Education, 46(4), 437-459.

Thompson, J. (2019). Mobility in the Middle: Bachelor's Degree Selectivity and the Intergenerational Association in Status in the United States. Research in Social Stratification and Mobility, 60, 16-28.

Torche, F. (2011). Is a College degree still the great equalizer? Intergenerational mobility across levels of schooling in the United States. American Journal of Sociology, 117(3), 763807.

Torche, F. (2018). Intergenerational mobility at the top of the educational distribution. Sociology of Education, 91(4), 266-289.

Triventi, M. (2013). The Role of Higher Education Stratification in the Reproduction of Social Inequality in the Labor Market. Research in Social Stratification and Mobility, 32, 4563.

University of London. Institute of Education. Centre for Longitudinal Studies. (2016a). 1970

British Cohort Study: Twenty-Nine-Year Follow-Up, 1999-2000. [data collection]. 4th 
Edition. Joint Centre for Longitudinal Research, [original data producer(s)]. UK Data Service. SN: 5558, http://doi.org/10.5255/UKDA-SN-5558-3

University of London. Institute of Education. Centre for Longitudinal Studies. (2016b). 1970 British Cohort Study: Thirty-Four-Year Follow-Up, 2004-2005. [data collection]. 4th Edition. UK Data Service. SN: 5585, http://doi.org/10.5255/UKDA-SN-5585-3

University of London. Institute of Education. Centre for Longitudinal Studies. (2016c). 1970 British Cohort Study: Thirty-Eight-Year Follow-Up, 2008-2009. [data collection]. 4th Edition. UK Data Service. SN: 6557, http://doi.org/10.5255/UKDA-SN-6557-3

University of London. Institute of Education. Centre for Longitudinal Studies. (2016c). 1970 British Cohort Study: Forty-Two-Year Follow-Up, 2012. [data collection]. 2nd Edition. UK Data Service. SN: 7473, http://doi.org/10.5255/UKDA-SN-7473-2

University of London. Institute of Education. Centre for Longitudinal Studies. (2017). 1970 British Cohort Study: Activity Histories, 1986-2013. [data collection]. 3rd Edition. UK Data Service. SN: 6943, http://doi.org/10.5255/UKDA-SN-6943-3

Walker, I., \& Zhu, Y. (2018). University selectivity and the relative returns to higher education: Evidence from the UK. Labour Economics, 53(May), 230-249.

Walpole, M. (2003). Socioeconomic Status and College: How SES Affects College Experiences and Outcomes. Review of Higher Education, 27(1), 45-73.

Witteveen, D., \& Attewell, P. (2017). The earnings payoff from attending a selective college. Social Science Research, 66, 154-169.

Zhang, L. (2005). Does quality pay? New York: Routledge. 
Table 1. Summary statistics ( $N=135,962$ person-months; 939 graduates)

\begin{tabular}{|c|c|c|c|c|}
\hline & Mean/proportion & SD & Min & Max \\
\hline SIOPS prestige score & 55.20 & 11.32 & 15.00 & 78.00 \\
\hline Months since first significant job & 81.81 & 48.24 & 1.00 & 168.00 \\
\hline \multicolumn{5}{|l|}{ HE institution } \\
\hline Russell Group & 0.33 & & & \\
\hline Other & 0.67 & & & \\
\hline \multicolumn{5}{|l|}{ Field of study } \\
\hline Humanities & 0.28 & & & \\
\hline Social sciences & 0.40 & & & \\
\hline STEM & 0.32 & & & \\
\hline \multicolumn{5}{|l|}{ Type of degree } \\
\hline Undergraduate & 0.87 & & & \\
\hline Postgraduate & 0.13 & & & \\
\hline \multicolumn{5}{|l|}{ Class of degree } \\
\hline $1^{\text {st }}$ & 0.09 & & & \\
\hline $2: 1$ & 0.43 & & & \\
\hline $2: 2$ & 0.35 & & & \\
\hline $3^{\text {rd }}$ or pass & 0.14 & & & \\
\hline \multicolumn{5}{|l|}{ Mode of study } \\
\hline Full-time & 0.94 & & & \\
\hline Part-time & 0.06 & & & \\
\hline \multicolumn{5}{|l|}{ Gender } \\
\hline Female & 0.51 & & & \\
\hline Male & 0.49 & & & \\
\hline \multicolumn{5}{|l|}{ Ethnic origin } \\
\hline UK & 0.96 & & & \\
\hline Non-UK & 0.04 & & & \\
\hline \multicolumn{5}{|l|}{ Class of origin } \\
\hline Working class & 0.12 & & & \\
\hline Intermediate class & 0.33 & & & \\
\hline Salariat class & 0.55 & & & \\
\hline \multicolumn{5}{|l|}{ Parental education } \\
\hline At least one parent with a degree & 0.46 & & & \\
\hline
\end{tabular}




\begin{tabular}{|c|c|c|c|c|}
\hline Both parents with no degree & 0.54 & & & \\
\hline $\begin{array}{l}\text { Cognitive ability (standardized) } \\
\text { at age } 10\end{array}$ & 112.81 & 12.39 & 70.45 & 151.19 \\
\hline $\begin{array}{l}\text { Locus of control (standardized) } \\
\text { at age } 10 \\
\text { Secondary school qualification }\end{array}$ & 0.53 & 0.90 & -2.50 & 2.64 \\
\hline No A-levels or equivalent & 0.16 & & & \\
\hline 1 A-level or equivalent & 0.15 & & & \\
\hline $2+$ A-levels or equivalent & 0.69 & & & \\
\hline \multicolumn{5}{|l|}{ Type of secondary school } \\
\hline Comprehensive & 0.72 & & & \\
\hline Independent & 0.14 & & & \\
\hline Grammar & 0.09 & & & \\
\hline Secondary Modern & 0.05 & & & \\
\hline \multicolumn{5}{|l|}{ Marital status } \\
\hline Single & 0.57 & & & \\
\hline Married & 0.41 & & & \\
\hline Divorced & 0.03 & & & \\
\hline \multicolumn{5}{|l|}{ Number of children } \\
\hline Zero & 0.72 & & & \\
\hline One & 0.13 & & & \\
\hline Two & 0.12 & & & \\
\hline Three or more & 0.03 & & & \\
\hline \multicolumn{5}{|l|}{ Employment status } \\
\hline Full-time & 0.90 & & & \\
\hline Part-time & 0.10 & & & \\
\hline
\end{tabular}

Source: BCS70, own calculations. Note: Statistics pertain to complete cases in the analytical sample and are weighted to correct for nonrandom loss to follow-up. 
Table 2. Summary of growth curve models predicting occupational prestige ( $N=135,962$ person-months, 939 graduates)

\begin{tabular}{|c|c|c|c|c|c|c|}
\hline & M0 & M1 & M2 & M3 & M4 & M5 \\
\hline \multirow[t]{2}{*}{24 months ( 2 yrs) or less } & & $0.145^{* * *}$ & $0.145^{* * *}$ & $0.145^{* * *}$ & $0.136^{* * *}$ & $0.136^{* * *}$ \\
\hline & & $(0.016)$ & $(0.016)$ & $(0.016)$ & $(0.016)$ & $(0.016)$ \\
\hline \multirow[t]{2}{*}{$25-48$ months (3-4 yrs) } & & $0.028^{*}$ & $0.028^{*}$ & $0.028^{*}$ & $0.025^{*}$ & $0.029^{*}$ \\
\hline & & $(0.012)$ & $(0.012)$ & $(0.012)$ & $(0.012)$ & $(0.012)$ \\
\hline \multirow[t]{2}{*}{ 49-72 months (5-6 yrs) } & & 0.020 & 0.020 & 0.020 & 0.017 & $0.024^{*}$ \\
\hline & & $(0.011)$ & $(0.011)$ & $(0.011)$ & $(0.011)$ & $(0.011)$ \\
\hline \multirow[t]{2}{*}{ 73-96 months (7-8 yrs) } & & $0.041^{* * *}$ & $0.041^{* * *}$ & $0.041^{* * *}$ & $0.037^{* *}$ & $0.048^{* * *}$ \\
\hline & & $(0.012)$ & $(0.012)$ & $(0.012)$ & $(0.012)$ & $(0.012)$ \\
\hline \multirow[t]{2}{*}{$97-120$ months (9-10 yrs) } & & 0.017 & 0.017 & 0.017 & 0.014 & $0.024^{*}$ \\
\hline & & $(0.010)$ & $(0.010)$ & $(0.010)$ & $(0.010)$ & $(0.011)$ \\
\hline \multirow[t]{2}{*}{$121-144$ months (11-12 yrs) } & & 0.013 & 0.013 & 0.013 & 0.011 & $0.021^{*}$ \\
\hline & & $(0.009)$ & $(0.009)$ & $(0.009)$ & $(0.009)$ & $(0.010)$ \\
\hline \multirow[t]{2}{*}{$145-168$ months (13-14 yrs) } & & -0.000 & -0.000 & -0.000 & -0.002 & 0.007 \\
\hline & & $(0.010)$ & $(0.010)$ & $(0.010)$ & $(0.010)$ & $(0.010)$ \\
\hline Russell Group (ref. Other) & & & $2.400^{* * *}$ & $1.555^{*}$ & 1.248 & 1.130 \\
\hline
\end{tabular}




\begin{tabular}{|c|c|c|c|c|c|c|}
\hline & & & $(0.666)$ & $(0.676)$ & $(0.721)$ & $(0.722)$ \\
\hline \multirow[t]{2}{*}{ Intercept } & $55.055^{* * *}$ & $50.370^{* * *}$ & $49.578^{* * *}$ & $49.632^{* * *}$ & $52.188^{* * *}$ & $52.233^{* * *}$ \\
\hline & $(0.311)$ & $(0.477)$ & $(0.509)$ & $(1.052)$ & $(2.631)$ & $(2.604)$ \\
\hline Controls & - & - & - & Selection & HE charac. & $\begin{array}{l}\text { Family } \\
\text { form. }\end{array}$ \\
\hline \multicolumn{7}{|l|}{ Variance components } \\
\hline Between-individual & 90.40 & 89.48 & 88.20 & 84.99 & 88.95 & 89.56 \\
\hline Within-individual & 41.58 & 39.16 & 39.16 & 39.16 & 38.67 & 38.37 \\
\hline Intraclass correlation (rho) & 0.68 & 0.70 & 0.69 & 0.69 & 0.70 & 0.70 \\
\hline $\mathrm{Chi}^{2}$ & - & 156.46 & 172.50 & 212.00 & 251.14 & 264.72 \\
\hline
\end{tabular}


Figure 1. Predicted occupational prestige by institutional prestige

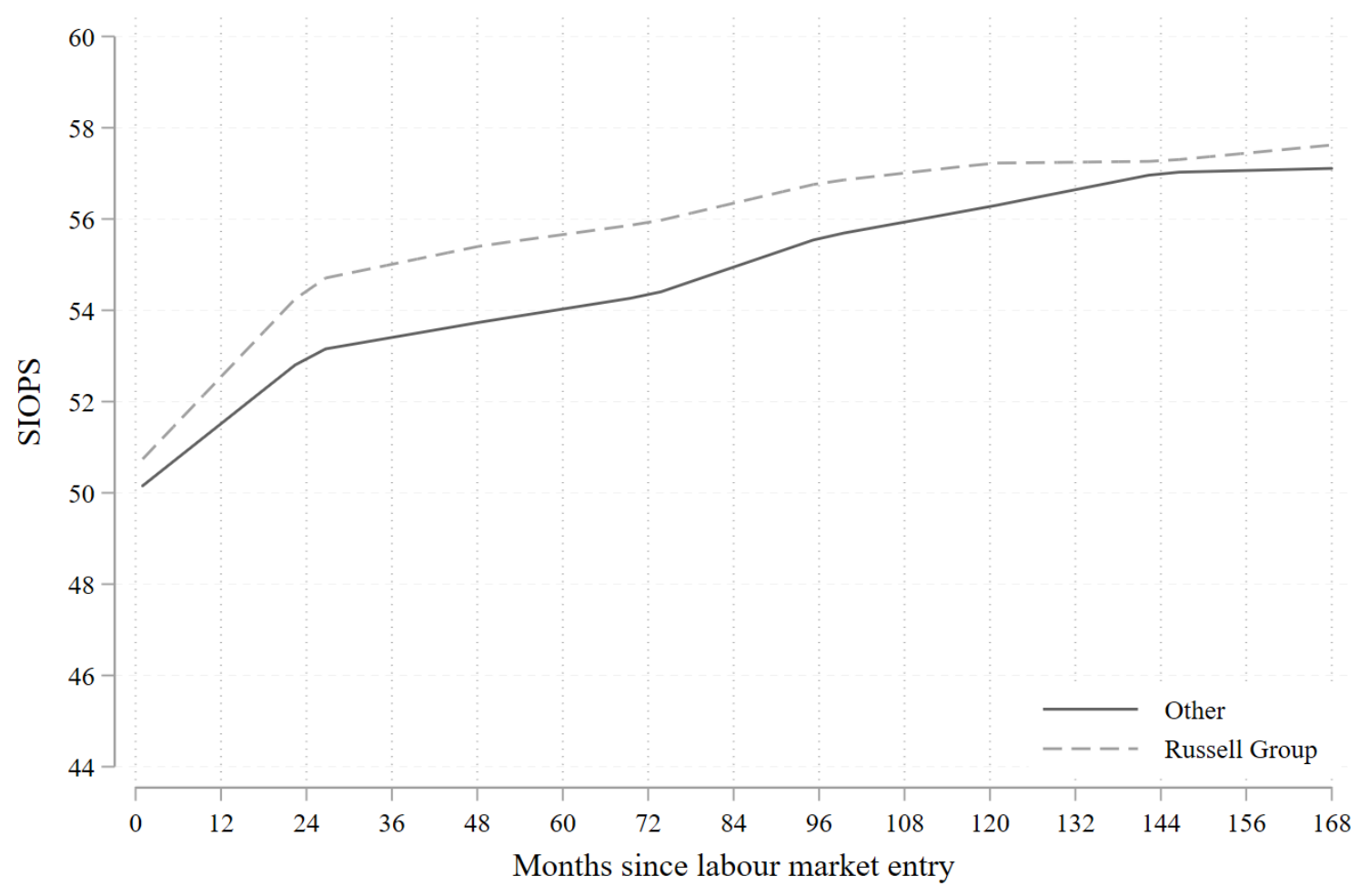

Source: BCS70, own calculations. Note: Predicted scores obtained from model M6 in Table S5 in the Supplementary Material. 
Figure 2. Predicted occupational prestige by institutional prestige and parental education
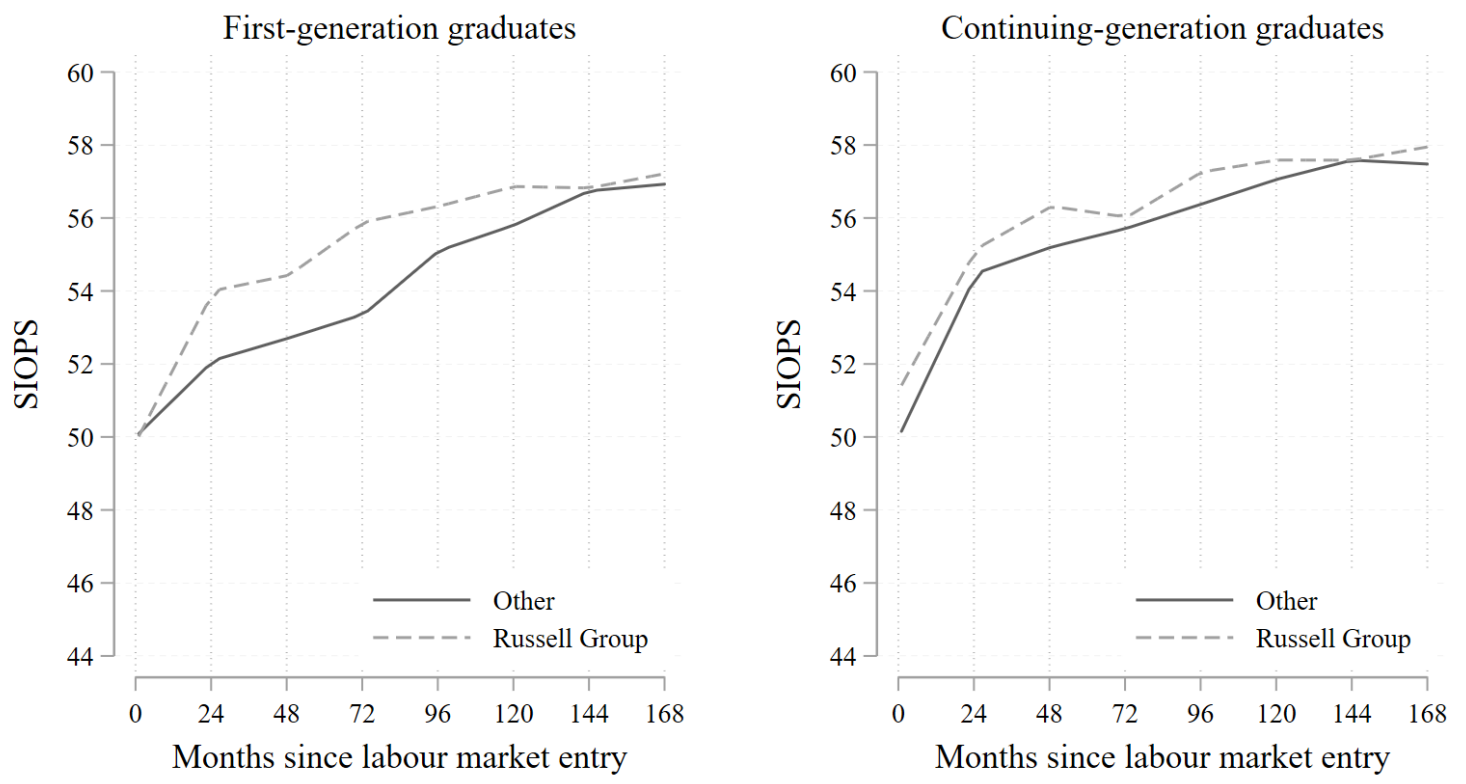

Source: BCS70, own calculations. Note: Respective predicted scores obtained from models M7 and M8 in Table S6 in the Supplementary Material. 
Supplementary Material: Who benefits from attending elite universities? Family background and graduates' career trajectories

Table S1. Summary of model for estimating the denominator of attrition weight (logistic regression)

\begin{tabular}{|c|c|}
\hline & $\begin{array}{c}\text { Denominator } \\
\text { Attrition weight }\end{array}$ \\
\hline $\begin{array}{l}\text { Cognitive ability (standardized) at } \\
\text { age } 10\end{array}$ & $\begin{array}{l}-.020^{* * *} \\
(.002)\end{array}$ \\
\hline $\begin{array}{l}\text { Locus of control (standardized) } \\
\text { at age } 10\end{array}$ & $\begin{array}{l}.023 \\
(.024)\end{array}$ \\
\hline $\begin{array}{l}\text { At least one parent with a degree } \\
\text { (ref. both parents with no degree) }\end{array}$ & $\begin{array}{l}-.027 \\
(.072)\end{array}$ \\
\hline $\begin{array}{l}\text { Ethnic origin (ref. } \\
\text { English/Northern Irish) }\end{array}$ & \\
\hline Welsh & $\begin{array}{c}.083 \\
(.094)\end{array}$ \\
\hline Scottish & $\begin{array}{l}.405^{* * *} \\
(.069)\end{array}$ \\
\hline European & $\begin{array}{l}.261 \\
(.249)\end{array}$ \\
\hline Indian/Pakistani/Bangladeshi & $\begin{array}{l}.126 \\
(.140)\end{array}$ \\
\hline Other & $\begin{array}{l}.782 \\
(.511)\end{array}$ \\
\hline $\begin{array}{l}\text { Class of origin (ref. higher } \\
\text { managerial and professional } \\
\text { occupations) }\end{array}$ & \\
\hline $\begin{array}{l}\text { Lower managerial and } \\
\text { professional occupations }\end{array}$ & -.053 \\
\hline Intermediate occupations & $\begin{array}{l}(.000) \\
.083 \\
(.092)\end{array}$ \\
\hline $\begin{array}{l}\text { Small employers and account } \\
\text { workers }\end{array}$ & $\begin{array}{l}.027 \\
(.104)\end{array}$ \\
\hline $\begin{array}{l}\text { Lower supervisory and technical } \\
\text { occupations }\end{array}$ & .157 \\
\hline Semi-routine occupations & $\begin{array}{l}.240^{*} \\
(.094)\end{array}$ \\
\hline Routine occupations & $\begin{array}{l}.250^{*} \\
(.099)\end{array}$ \\
\hline Constant & $\begin{array}{c}1.229^{* * *} \\
(.195) \\
\end{array}$ \\
\hline $\mathrm{N}$ & 9232 \\
\hline
\end{tabular}


Table S2. Descriptive statistics for inverse probability of attrition weight (AW)

\begin{tabular}{|c|c|c|c|c|c|}
\hline \multirow[b]{2}{*}{$M$} & \multirow[b]{2}{*}{$S D$} & \multicolumn{4}{|c|}{ Percentiles } \\
\hline & & $1^{s t}$ & $25^{\text {th }}$ & $75^{\text {th }}$ & $99^{\text {th }}$ \\
\hline 1.00 & 0.13 & 0.80 & 0.90 & 1.07 & 1.41 \\
\hline
\end{tabular}

Source: BCS70, own calculations. Note: Statistics pertain to sample not lost to follow-up. 
Table S3. Summary statistics for first-generation graduates $(\mathrm{N}=71,721$ person-months, 501 graduates $)$ and continuing-generation graduates $(\mathrm{N}=$ 64,241 person-months, 438 graduates)

\begin{tabular}{|c|c|c|c|c|c|c|c|c|}
\hline & \multicolumn{4}{|c|}{ First-generation } & \multicolumn{4}{|c|}{ Continuing-generation } \\
\hline & Mean/Proportion & SD & Min & Max & Mean/Proportion & SD & Min & Max \\
\hline SIOPS prestige score & 54.60 & 11.33 & 15.00 & 78.00 & 56.15 & 11.31 & 15.00 & 78.00 \\
\hline $\begin{array}{l}\text { Months since first significant } \\
\text { job } \\
\text { HE institution }\end{array}$ & 81.30 & 48.05 & 1.00 & 168.00 & 82.44 & 48.50 & 1.00 & 168.00 \\
\hline Russell Group & 0.28 & & & & 0.40 & & & \\
\hline Other & 0.72 & & & & 0.60 & & & \\
\hline \multicolumn{9}{|l|}{ Field of study } \\
\hline Humanities & 0.29 & & & & 0.27 & & & \\
\hline Social sciences & 0.37 & & & & 0.44 & & & \\
\hline STEM & 0.35 & & & & 0.29 & & & \\
\hline \multicolumn{9}{|l|}{ Type of degree } \\
\hline Undergraduate & 0.87 & & & & 0.86 & & & \\
\hline Postgraduate & 0.13 & & & & 0.14 & & & \\
\hline \multicolumn{9}{|l|}{ Class of degree } \\
\hline $1^{\text {st }}$ & 0.10 & & & & 0.07 & & & \\
\hline $2: 1$ & 0.38 & & & & 0.50 & & & \\
\hline $2: 2$ & 0.38 & & & & 0.30 & & & \\
\hline $3^{\text {rd }}$ or pass & 0.14 & & & & 0.13 & & & \\
\hline Mode of study & & & & & & & & \\
\hline
\end{tabular}




\begin{tabular}{|c|c|c|c|c|c|c|c|c|}
\hline Full-time & 0.92 & & & & 0.96 & & & \\
\hline Part-time & 0.08 & & & & 0.04 & & & \\
\hline \multicolumn{9}{|l|}{ Gender } \\
\hline Female & 0.47 & & & & 0.55 & & & \\
\hline Male & 0.53 & & & & 0.45 & & & \\
\hline \multicolumn{9}{|l|}{ Ethnic origin } \\
\hline UK & 0.95 & & & & 0.98 & & & \\
\hline Non-UK & 0.05 & & & & 0.02 & & & \\
\hline \multicolumn{9}{|l|}{ Class of origin } \\
\hline Working class & 0.18 & & & & 0.03 & & & \\
\hline Intermediate class & 0.51 & & & & 0.13 & & & \\
\hline Salariat class & 0.32 & & & & 0.85 & & & \\
\hline $\begin{array}{l}\text { Cognitive ability } \\
\text { (standardized) at age } 10\end{array}$ & 111.45 & 12.73 & 70.45 & 151.19 & 116.48 & 10.92 & 79.00 & 148.96 \\
\hline $\begin{array}{l}\text { Locus of control } \\
\text { (standardized) } \\
\text { at age } 10 \\
\text { Secondary school qualification }\end{array}$ & 0.42 & 0.90 & -2.50 & 2.30 & 0.69 & 0.86 & -1.82 & 2.64 \\
\hline No A-levels or equivalent & 0.20 & & & & 0.09 & & & \\
\hline $1 \mathrm{~A}$-level or equivalent & 0.15 & & & & 0.14 & & & \\
\hline $2+$ A-levels or equivalent & 0.65 & & & & 0.77 & & & \\
\hline \multicolumn{9}{|l|}{ Type of secondary school } \\
\hline Comprehensive & 0.75 & & & & 0.67 & & & \\
\hline Independent & 0.10 & & & & 0.20 & & & \\
\hline
\end{tabular}




\begin{tabular}{lll}
\hline Grammar & 0.08 & 0.11 \\
Secondary Modern & 0.07 & 0.02 \\
Marital status & & 0.59 \\
Single & 0.55 & 0.39 \\
Married & 0.41 & 0.02 \\
Divorced & 0.04 & \\
Number of children & & 0.74 \\
Zero & 0.71 & 0.13 \\
One & 0.14 & 0.11 \\
Two & 0.12 & 0.03 \\
Three or more & 0.03 & \\
Employment status & & 0.90 \\
Full-time & 0.90 & 0.10 \\
Part-time & 0.10 & \\
\hline Sourc: BCS70, & & \\
\hline
\end{tabular}

Source: BCS70, own calculations. Note: Statistics pertain to complete cases in the analytical sample and are weighted to correct for nonrandom loss to follow-up. 
Table S4. Summary of growth curve models predicting occupational prestige (N=135,962 person-months; 939 graduates)

\begin{tabular}{|c|c|c|c|c|c|c|}
\hline & Mo & M1 & M2 & M3 & M4 & M5 \\
\hline \multirow[t]{2}{*}{24 months ( 2 yrs) or less } & & $0.145^{* * *}$ & $0.145^{* * *}$ & $0.145^{* * *}$ & $0.136^{* * *}$ & $0.136^{* * *}$ \\
\hline & & $(0.016)$ & $(0.016)$ & $(0.016)$ & $(0.016)$ & $(0.016)$ \\
\hline \multirow[t]{2}{*}{$25-48$ months (3-4 yrs) } & & $0.028^{*}$ & $0.028^{*}$ & $0.028^{*}$ & $0.025^{*}$ & $0.029^{*}$ \\
\hline & & $(0.012)$ & $(0.012)$ & $(0.012)$ & $(0.012)$ & $(0.012)$ \\
\hline \multirow[t]{2}{*}{ 49-72 months (5-6 yrs) } & & 0.020 & 0.020 & 0.020 & 0.017 & $0.024^{*}$ \\
\hline & & $(0.011)$ & $(0.011)$ & $(0.011)$ & $(0.011)$ & $(0.011)$ \\
\hline \multirow[t]{2}{*}{ 73-96 months (7-8 yrs) } & & $0.041^{* * *}$ & $0.041^{* * *}$ & $0.041^{* * *}$ & $0.037^{* *}$ & $0.048^{* * *}$ \\
\hline & & $(0.012)$ & $(0.012)$ & $(0.012)$ & $(0.012)$ & $(0.012)$ \\
\hline \multirow[t]{2}{*}{$97-120$ months (9-10 yrs) } & & 0.017 & 0.017 & 0.017 & 0.014 & $0.024^{*}$ \\
\hline & & $(0.010)$ & $(0.010)$ & $(0.010)$ & $(0.010)$ & $(0.011)$ \\
\hline \multirow[t]{2}{*}{$121-144$ months (11-12 yrs) } & & 0.013 & 0.013 & 0.013 & 0.011 & $0.021^{*}$ \\
\hline & & $(0.009)$ & $(0.009)$ & $(0.009)$ & $(0.009)$ & $(0.010)$ \\
\hline \multirow[t]{2}{*}{ 145-168 months (13-14 yrs) } & & -0.000 & -0.000 & -0.000 & -0.002 & 0.007 \\
\hline & & $(0.010)$ & $(0.010)$ & $(0.010)$ & $(0.010)$ & $(0.010)$ \\
\hline \multirow[t]{2}{*}{ Russell Group (ref. Other) } & & & $2.400^{* * *}$ & $1.555^{*}$ & 1.248 & 1.130 \\
\hline & & & $(0.666)$ & $(0.676)$ & $(0.721)$ & $(0.722)$ \\
\hline \multirow[t]{2}{*}{ Female (ref. male) } & & & & $-1.262^{*}$ & -1.109 & -0.815 \\
\hline & & & & $(0.614)$ & $(0.833)$ & $(0.833)$ \\
\hline Non-UK origin (ref. UK) & & & & -0.371 & -0.877 & -0.877 \\
\hline
\end{tabular}




\begin{tabular}{|c|c|c|c|}
\hline & $(1.567)$ & $(1.615)$ & $(1.636)$ \\
\hline \multirow{2}{*}{$\begin{array}{l}\text { At least one parent with a } \\
\text { degree (ref. both parents } \\
\text { with no degree) }\end{array}$} & 0.718 & 0.222 & 0.176 \\
\hline & $(0.713)$ & $(0.752)$ & $(0.755)$ \\
\hline \multicolumn{4}{|l|}{$\begin{array}{l}\text { Parental class (ref. Salariat } \\
\text { class) }\end{array}$} \\
\hline \multirow[t]{2}{*}{ Intermediate class } & 0.471 & 0.304 & 0.422 \\
\hline & $(0.778)$ & $(0.803)$ & $(0.805)$ \\
\hline \multirow[t]{2}{*}{ Working class } & -0.203 & 0.495 & 0.523 \\
\hline & $(1.062)$ & $(1.184)$ & $(1.185)$ \\
\hline \multirow[t]{2}{*}{ Cognitive ability } & $0.075^{* *}$ & $0.067^{*}$ & $0.065^{*}$ \\
\hline & $(0.027)$ & $(0.030)$ & $(0.030)$ \\
\hline \multirow[t]{2}{*}{ Locus of control } & -0.019 & -0.250 & -0.206 \\
\hline & $(0.355)$ & $(0.380)$ & $(0.382)$ \\
\hline \multicolumn{4}{|l|}{$\begin{array}{l}\text { Secondary school } \\
\text { qualifications (ref. no A- } \\
\text { level) }\end{array}$} \\
\hline \multirow[t]{2}{*}{1 A-level } & 0.160 & -0.374 & -0.666 \\
\hline & $(1.126)$ & $(1.240)$ & $(1.240)$ \\
\hline \multirow[t]{2}{*}{$2+$ A-levels } & -0.062 & -0.157 & -0.524 \\
\hline & $(0.842)$ & $(0.926)$ & $(0.935)$ \\
\hline \multicolumn{4}{|l|}{$\begin{array}{l}\text { Secondary school type (ref. } \\
\text { Comprehensive) }\end{array}$} \\
\hline \multirow[t]{2}{*}{ Grammar } & -0.464 & -0.755 & -0.583 \\
\hline & $(1.067)$ & $(1.078)$ & (1.079) \\
\hline
\end{tabular}




\begin{tabular}{lccc}
\hline Secondary Modern & 0.150 & -0.234 & -0.212 \\
& $(0.887)$ & $(1.160)$ & $(1.164)$ \\
Independent & $3.376^{* * *}$ & $3.165^{* *}$ & $3.157^{* *}$ \\
& $(0.963)$ & $(0.971)$ & $(0.978)$ \\
Postgraduate (ref. & & $5.253^{* * *}$ & $5.095^{* * *}$ \\
undergraduate) & & $(1.385)$ & $(1.388)$ \\
Field of study (ref. & & \\
humanities) & & & 2.236 \\
Social sciences & & $(1.848)$ & $(1.858)$ \\
STEM fields & & -0.010 & -0.203 \\
& & $(1.810)$ & $(1.798)$ \\
Class of degree (ref. 1 st $)$ & & & -0.725 \\
2:1 & & -1.450 & $(2.813)$ \\
& & $(2.819)$ & $-7.564^{* *}$ \\
2:2 & & $-7.999^{* *}$ & $(2.882)$ \\
Part-time studies (ref. full- & & $(2.968)$ & 0.328 \\
time studies) & & 0.068 & $(2.181)$ \\
Marital status (ref. Single) & & $(2.176)$ & -1.189 \\
\hline
\end{tabular}




\begin{tabular}{|c|c|c|c|c|c|c|}
\hline \multirow[t]{2}{*}{ Married } & & & & & & -0.245 \\
\hline & & & & & & $(0.387)$ \\
\hline \multirow[t]{2}{*}{ Divorced } & & & & & & $-2.382^{*}$ \\
\hline & & & & & & (1.194) \\
\hline \multirow[t]{2}{*}{$\mathrm{N}$ children } & & & & & & $-0.626^{*}$ \\
\hline & & & & & & $(0.256)$ \\
\hline \multirow{2}{*}{$\begin{array}{l}\text { Part-time employment (ref. } \\
\text { full-time) }\end{array}$} & & & & & & \\
\hline & & & & & & $(0.808)$ \\
\hline \multirow[t]{2}{*}{ Intercept } & $55.055^{* * *}$ & $50.370^{* * *}$ & $49.578^{* * *}$ & $49.632^{* * *}$ & $52.188^{* * *}$ & $52.233^{* * *}$ \\
\hline & $(0.311)$ & $(0.477)$ & $(0.509)$ & $(1.052)$ & $(2.631)$ & $(2.604)$ \\
\hline \multicolumn{7}{|l|}{ Variance components } \\
\hline Between-individual & 90.40 & 89.48 & 88.20 & 84.99 & 88.95 & 89.56 \\
\hline Within-individual & 41.58 & 39.16 & 39.16 & 39.16 & 38.67 & 38.37 \\
\hline Intraclass correlation (rho) & 0.68 & 0.70 & 0.69 & 0.69 & 0.70 & 0.70 \\
\hline $\mathrm{Chi}^{2}$ & - & 156.46 & 172.50 & 212.00 & 251.14 & 264.72 \\
\hline
\end{tabular}


Table S5. Growth curve models predicting occupational prestige by institutional prestige ( $\mathrm{N}=135,962$ person-months from 939 graduates)

\section{M6}

24 months ( 2 yrs) or less

$0.124^{* * *}$

$(0.019)$

25-48 months (3-4 yrs)

0.027

$(0.015)$

49-72 months (5-6 yrs)

0.025

$(0.014)$

73-96 months (7-8 yrs)

$0.053^{* * *}$

$(0.015)$

97-120 months (9-10 yrs)

$0.028^{*}$

(0.013)

121-144 months (11-12 yrs)

$0.031^{* *}$

(0.011)

145-168 months (13-14 yrs)

0.004

(0.013)

Russell Group (ref. Other)

0.545

(1.050)

Female (ref. male)

$-0.811$

$(0.834)$

Non-UK origin (ref. UK)

$-0.871$

At least one parent with a degree (ref.

both parents with no degree)

Parental class (ref. Salariat class)

Intermediate class

Working class

Cognitive ability

Locus of control

$-0.204$

$(0.381)$

Secondary school qualifications (ref. no 


\begin{tabular}{|c|c|}
\hline \multicolumn{2}{|l|}{ A-level) } \\
\hline \multirow[t]{2}{*}{1 A-level } & -0.680 \\
\hline & $(1.240)$ \\
\hline \multirow[t]{2}{*}{$2+$ A-levels } & -0.536 \\
\hline & $(0.936)$ \\
\hline \multicolumn{2}{|l|}{$\begin{array}{l}\text { Secondary school type (ref. } \\
\text { Comprehensive) }\end{array}$} \\
\hline \multirow[t]{2}{*}{ Grammar } & -0.568 \\
\hline & $(1.078)$ \\
\hline \multirow[t]{2}{*}{ Secondary Modern } & -0.208 \\
\hline & $(1.161)$ \\
\hline \multirow[t]{2}{*}{ Independent } & $3.163^{* *}$ \\
\hline & $(0.977)$ \\
\hline \multirow[t]{2}{*}{ Postgraduate (ref. undergraduate) } & $5.124^{* * *}$ \\
\hline & $(1.396)$ \\
\hline \multicolumn{2}{|l|}{ Field of study (ref. humanities) } \\
\hline \multirow[t]{2}{*}{ Social sciences } & 2.251 \\
\hline & $(1.829)$ \\
\hline \multirow[t]{2}{*}{ STEM fields } & -0.143 \\
\hline & $(1.793)$ \\
\hline \multicolumn{2}{|l|}{ Class of degree (ref. $1^{\text {st }}$ ) } \\
\hline \multirow[t]{2}{*}{$2: 1$} & -0.621 \\
\hline & $(2.802)$ \\
\hline \multirow[t]{2}{*}{$2: 2$} & $-7.439^{* *}$ \\
\hline & $(2.869)$ \\
\hline \multirow[t]{2}{*}{ Third or pass } & 0.340 \\
\hline & $(2.141)$ \\
\hline \multirow[t]{2}{*}{ Part-time studies (ref. full-time studies) } & -1.160 \\
\hline & $(2.032)$ \\
\hline \multicolumn{2}{|l|}{ Marital status (ref. Single) } \\
\hline \multirow[t]{2}{*}{ Married } & -0.228 \\
\hline & $(0.387)$ \\
\hline \multirow[t]{2}{*}{ Divorced } & $-2.363^{*}$ \\
\hline & $(1.197)$ \\
\hline $\mathrm{N}$ children & $-0.645^{*}$ \\
\hline
\end{tabular}




\begin{tabular}{lc}
\hline & $(0.255)$ \\
Part-time employment (ref. full-time) & $-1.703^{*}$ \\
Russell Group*24 months & $(0.807)$ \\
& 0.040 \\
Russell Group*25-48 months & $(0.033)$ \\
& 0.005 \\
Russell Group*49-72 months & $(0.024)$ \\
Russell Group*73-96 months & -0.003 \\
Russell Group*97-120 months & $(0.022)$ \\
Russell Group*121-144 months & -0.016 \\
Russell Group*145-168 months & $(0.025)$ \\
Intercept & -0.011 \\
& $(0.022)$ \\
& -0.029 \\
& $(0.019)$ \\
& 0.011 \\
& $(0.021)$ \\
& $52.298^{* * *}$ \\
& $(2.591)$ \\
\hline
\end{tabular}

Variance components

Between-individual $\quad 89.47$

Within-individual $\quad 38.32$

Intraclass correlation (rho) $\quad 0.70$

$\begin{array}{ll}\mathrm{Chi}^{2} & 276.69\end{array}$

Source: BCS70, own calculations. Note: Robust standard errors in parentheses. " $p<0.05,{ }^{* *} p<0.01,{ }^{* * *} p<0.001$. All models weighted by inverse probability of attrition to correct for nonrandom loss to follow-up. 
Table S6. Growth curve models predicting occupational prestige by institutional prestige for firstgeneration graduates $(\mathrm{N}=71,721$ person-months from 501 graduates) and continuing-generation graduates ( $\mathrm{N}=64,241$ person-months from 438 graduates)

\begin{tabular}{|c|c|c|}
\hline & $\begin{array}{l}\text { M7 (First-generation } \\
\text { graduates) }\end{array}$ & $\begin{array}{c}\text { M8 (Continuing- } \\
\text { generation graduates) }\end{array}$ \\
\hline \multirow[t]{2}{*}{24 months ( 2 yrs) or less } & $0.084^{* * *}$ & $0.182^{* * *}$ \\
\hline & $(0.022)$ & $(0.033)$ \\
\hline \multirow[t]{2}{*}{ 25-48 months (3-4 yrs) } & 0.026 & 0.030 \\
\hline & $(0.019)$ & $(0.024)$ \\
\hline \multirow[t]{2}{*}{ 49-72 months (5-6 yrs) } & 0.027 & 0.022 \\
\hline & $(0.018)$ & $(0.021)$ \\
\hline \multirow[t]{2}{*}{ 73-96 months (7-8 yrs) } & $0.073^{* * *}$ & 0.028 \\
\hline & $(0.021)$ & $(0.022)$ \\
\hline \multirow[t]{2}{*}{ 97-120 months (9-10 yrs) } & 0.029 & 0.028 \\
\hline & $(0.018)$ & $(0.017)$ \\
\hline \multirow[t]{2}{*}{$121-144$ months (11-12 yrs) } & $0.039^{* *}$ & 0.022 \\
\hline & $(0.015)$ & $(0.017)$ \\
\hline \multirow[t]{2}{*}{$145-168$ months (13-14 yrs) } & 0.008 & -0.004 \\
\hline & $(0.018)$ & $(0.017)$ \\
\hline \multirow[t]{2}{*}{ Russell Group (ref. Other) } & -0.158 & 1.282 \\
\hline & $(1.385)$ & $(1.594)$ \\
\hline \multirow[t]{2}{*}{ Female (ref. male) } & -1.315 & -1.146 \\
\hline & $(1.370)$ & $(1.076)$ \\
\hline \multirow[t]{2}{*}{ Non-UK origin (ref. UK) } & 0.269 & -2.150 \\
\hline & $(2.084)$ & $(2.336)$ \\
\hline \multicolumn{3}{|c|}{ Parental class (ref. Salariat class) } \\
\hline \multirow[t]{2}{*}{ Intermediate class } & 0.035 & 1.668 \\
\hline & $(1.012)$ & $(1.436)$ \\
\hline \multirow[t]{2}{*}{ Working class } & 0.785 & -1.865 \\
\hline & $(1.380)$ & $(3.385)$ \\
\hline \multirow[t]{2}{*}{ Cognitive ability } & $0.089^{*}$ & 0.051 \\
\hline & $(0.042)$ & $(0.044)$ \\
\hline \multirow[t]{2}{*}{ Locus of control } & -0.240 & 0.078 \\
\hline & $(0.528)$ & $(0.579)$ \\
\hline $\begin{array}{l}\text { Secondary school qualificati } \\
\text { A-level) }\end{array}$ & & \\
\hline
\end{tabular}




\begin{tabular}{|c|c|c|}
\hline \multirow[t]{2}{*}{1 A-level } & -1.734 & 0.906 \\
\hline & $(1.591)$ & $(2.068)$ \\
\hline \multirow[t]{2}{*}{$2+$ A-levels } & -0.504 & -0.453 \\
\hline & $(1.206)$ & $(1.591)$ \\
\hline \multirow{2}{*}{\multicolumn{3}{|c|}{$\begin{array}{l}\text { Secondary school type (ref. } \\
\text { Comprehensive) }\end{array}$}} \\
\hline \multirow{2}{*}{ Grammar } & & \\
\hline & $(1660)$ & (1409) \\
\hline \multirow{3}{*}{ Secondary Modern } & & \\
\hline & 0.150 & -1.732 \\
\hline & $(1.200)$ & $(2.745)$ \\
\hline \multirow[t]{2}{*}{ Independent } & $3.187^{*}$ & $3.807^{* *}$ \\
\hline & $(1.592)$ & $(1.358)$ \\
\hline \multirow[t]{2}{*}{ Postgraduate (ref. undergraduate) } & $5.621^{*}$ & \\
\hline & $(2.362)$ & \\
\hline \multicolumn{3}{|l|}{ Field of study (ref. humanities) } \\
\hline \multirow[t]{2}{*}{ Social sciences } & -1.062 & 3.578 \\
\hline & $(2.946)$ & $(2.271)$ \\
\hline \multirow[t]{2}{*}{ STEM fields } & -4.667 & 2.452 \\
\hline & $(2.660)$ & $(2.440)$ \\
\hline \multicolumn{3}{|l|}{ Class of degree (ref. $1^{\text {st }}$ ) } \\
\hline \multirow[t]{2}{*}{$2: 1$} & 1.097 & -2.605 \\
\hline & $(5.764)$ & $(3.375)$ \\
\hline \multirow[t]{2}{*}{$2: 2$} & -4.227 & $-11.387^{* *}$ \\
\hline & $(4.337)$ & $(3.490)$ \\
\hline \multirow[t]{2}{*}{ Third or pass } & 2.391 & -2.051 \\
\hline & $(3.605)$ & $(2.374)$ \\
\hline \multirow[t]{2}{*}{ Part-time studies (ref. full-time studies) } & 1.849 & $-4.042^{*}$ \\
\hline & $(3.693)$ & $(1.945)$ \\
\hline \multicolumn{3}{|l|}{ Marital status (ref. Single) } \\
\hline \multirow[t]{2}{*}{ Married } & -0.132 & -0.358 \\
\hline & $(0.511)$ & $(0.585)$ \\
\hline \multirow[t]{2}{*}{ Divorced } & $-3.866^{*}$ & -0.106 \\
\hline & $(1.701)$ & $(1.310)$ \\
\hline \multirow[t]{2}{*}{$\mathrm{N}$ children } & $-0.790^{*}$ & -0.503 \\
\hline & $(0.341)$ & $(0.376)$ \\
\hline
\end{tabular}




\begin{tabular}{|c|c|c|}
\hline \multirow[t]{2}{*}{ Part-time employment (ref. full-time) } & $-2.908^{* *}$ & -0.508 \\
\hline & $(1.101)$ & $(1.152)$ \\
\hline \multirow[t]{2}{*}{ Russell Group*24 months } & $0.083^{*}$ & -0.025 \\
\hline & $(0.042)$ & $(0.051)$ \\
\hline \multirow[t]{2}{*}{ Russell Group*25-48 months } & -0.008 & 0.019 \\
\hline & $(0.029)$ & $(0.038)$ \\
\hline \multirow[t]{2}{*}{ Russell Group*49-72 months } & 0.034 & -0.034 \\
\hline & $(0.034)$ & $(0.030)$ \\
\hline \multirow[t]{2}{*}{ Russell Group*73-96 months } & -0.055 & 0.024 \\
\hline & $(0.035)$ & $(0.035)$ \\
\hline \multirow[t]{2}{*}{ Russell Group*97-120 months } & -0.007 & -0.015 \\
\hline & $(0.026)$ & $(0.033)$ \\
\hline \multirow[t]{2}{*}{ Russell Group*121-144 months } & -0.041 & -0.022 \\
\hline & $(0.025)$ & $(0.029)$ \\
\hline \multirow[t]{2}{*}{ Russell Group*145-168 months } & 0.009 & 0.020 \\
\hline & $(0.031)$ & $(0.029)$ \\
\hline \multirow[t]{2}{*}{ Intercept } & $52.298^{* * *}$ & $52.683^{* * *}$ \\
\hline & $(2.591)$ & $(3.752)$ \\
\hline \multicolumn{3}{|l|}{ Variance components } \\
\hline Between-individual & 91.55 & 91.92 \\
\hline Within-individual & 36.46 & 39.92 \\
\hline Intraclass correlation (rho) & 0.72 & 0.70 \\
\hline $\mathrm{Chi}^{2}$ & 180.85 & 152.93 \\
\hline
\end{tabular}


Figure S1. Predicted occupational prestige by university type

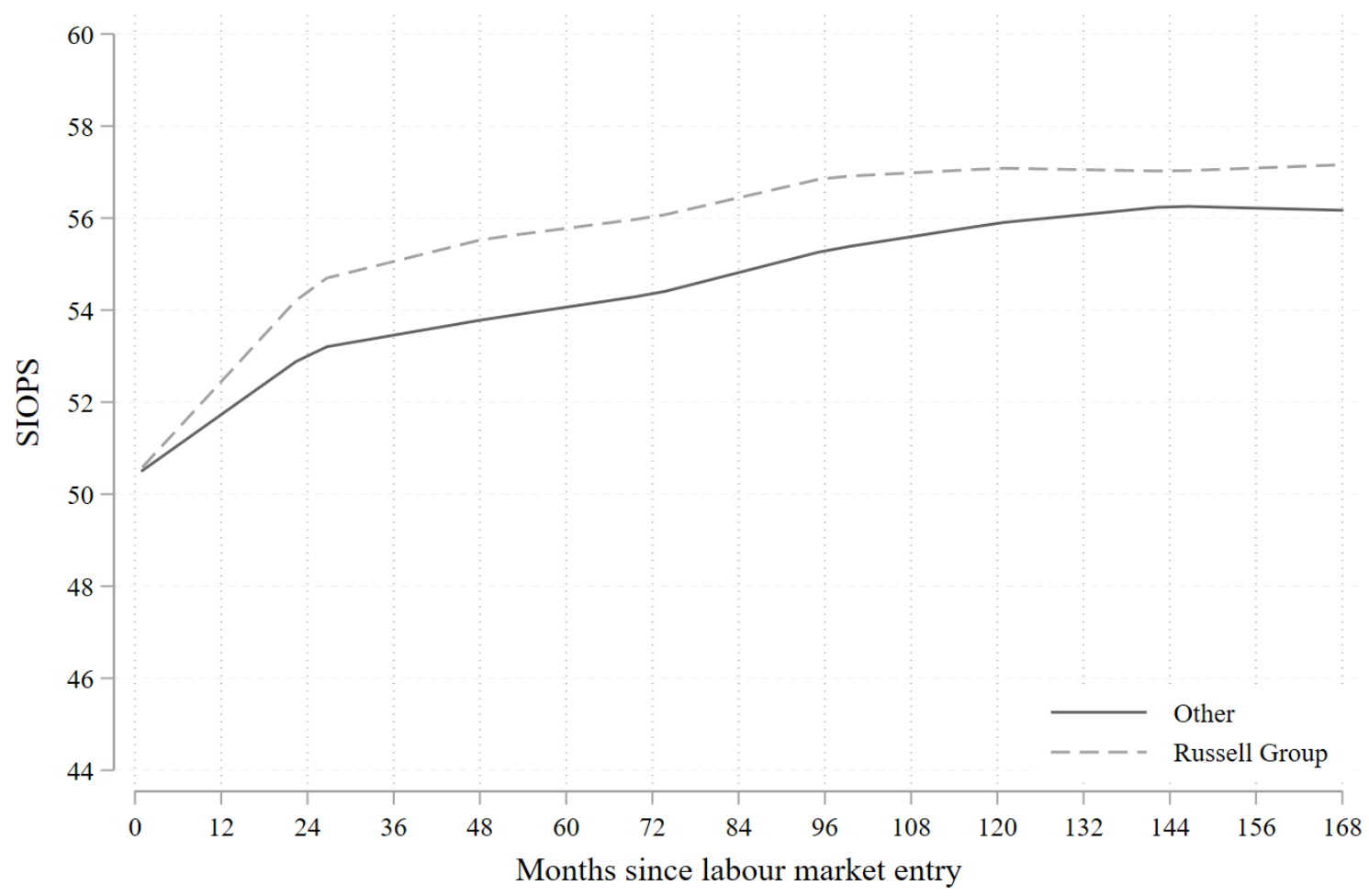

Source: BCS70, own calculations. Note: Predicted scores obtained from multilevel growth curve model including random slopes for 24-month splines. 
Figure S2. Predicted occupational prestige by university type

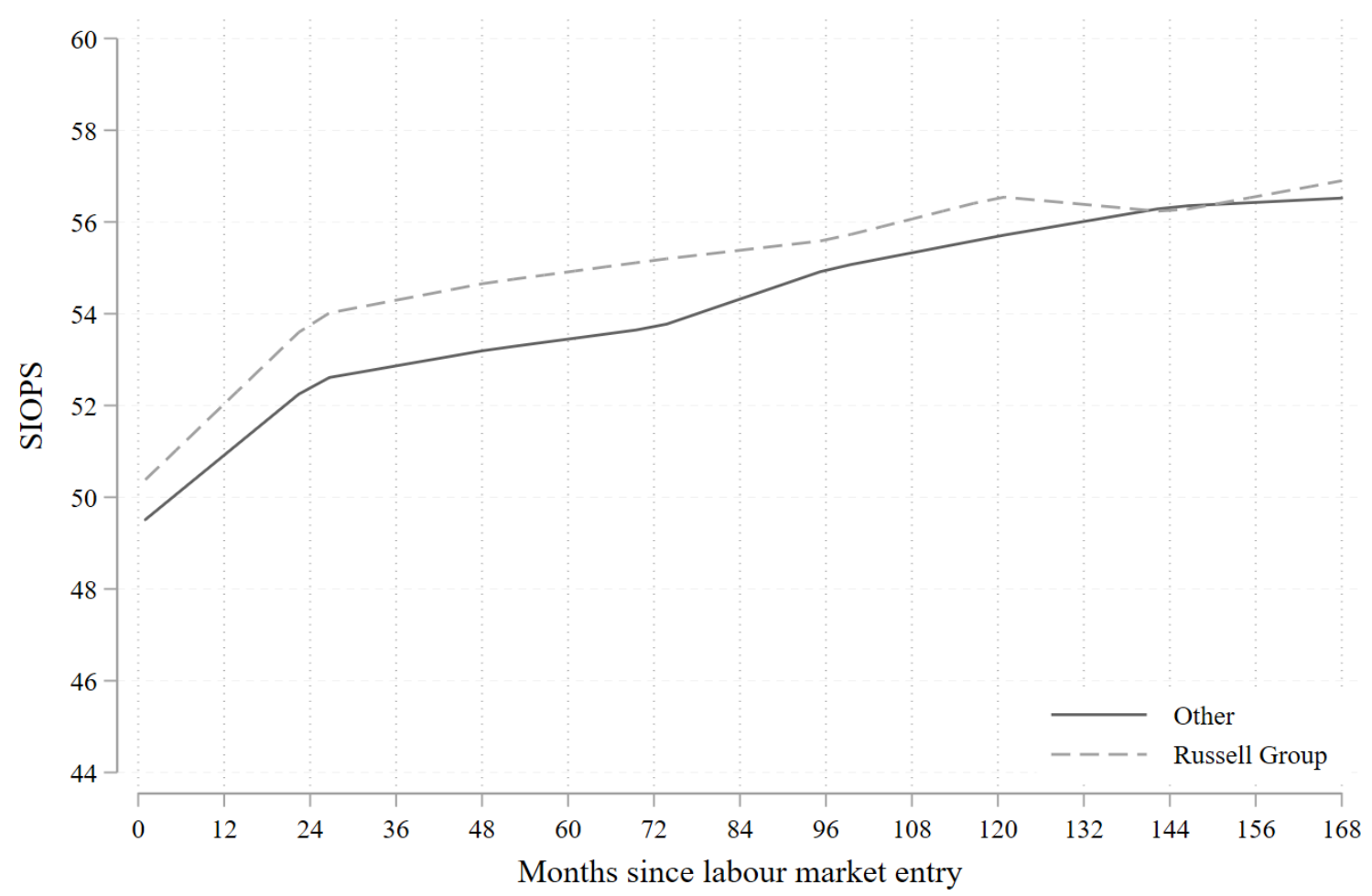

Source: BCS70, own calculations. Note: Predicted scores obtained from a model excluding job spells when graduates obtained postgraduate degrees $(\mathrm{N}=117,762$ person-months $)$. 